\title{
Taking Institutions Seriously: Introduction to a Strategy for Constitutional Analysis
}

\author{
Neil K. Komesar $†$
}

When the Supreme Court decides whether the action of another branch of government is constitutionally valid, it is inevitably allocating institutional responsibility. Sometimes the presence of this allocative choice is obvious; federalism or separation of powers questions, for example, are cast explicitly as choices among components of the political process. But the Court must make an institutional choice even when it invalidates an action, not because the action was taken by the wrong political body, but because it was taken at all. Whenever a political decision is declared invalid, the judgment of the judicial branch has been substituted for that of other branches of government.

This article argues that constitutional law is best understood and evaluated by giving central attention to this allocation of decisionmaking and, therefore, to the relative attributes of the alternative institutional decisionmakers. The article, in other words, proposes a comparative institutional approach to constitutional law. The logic of the approach is simple. When the Court addresses constitutional issues, it typically must choose a principal decisionmaker from among the various institutions of government, including the judiciary itself. Accordingly, it should, and to some extent does, consider the relative strengths and weaknesses of these institutions to address the social issue involved. These institutions differ from one another, and the force and implication of these differences vary from one type of social issue to another.

Certain standard maxims about institutional competence ap-

Copyright $\odot$ by Neil K. Komesar 1983

$\dagger$ Professor of Law, University of Wisconsin Law School, Madison.

Many colleagues and friends read and commented on this article at various stages in its evolution. I owe them a great debt for their insights and their support. They include Bill Clune, Ted Finman, David Goldberger, Joel Handler, Dirk Hartog, Willard Hurst, Philip Kurland, Mitchell Netburn, Tom Palay, Shelley Safer, Ted Schneyer, Eric Swanson, Mark Tushnet and Bill Whitford. I also owe thanks to my constitutional law classes and my comparative institutional analysis seminars for their patience, skepticism and enthusiasm.

I wish to thank the University of Wisconsin Foundation and the Smongeski Bequest as well as the University of Wisconsin Graduate School and Law School for their financial support. 
pear regularly in cases and commentary. The judiciary is relatively good at deciding issues of procedure and plays a relatively active role in such decisions. It is relatively poor at deciding issues of war and foreign affairs and entrusts these decisions largely to Congress and the President. It finds legislatures-state and federal-suspect when they pass legislation that disproportionately harms politically weak minorities or when they restrain activities that may affect the incumbency of the legislators themselves-such as voting, political association, and speech.

But these points, although they make up the core of existing institutional analysis, hardly scratch the surface. What should the Court do when a case involves war and criminal procedure, or foreign relations and politically weak minorities or restraints on speech and political association in time of war? Does concern about traditional minorities or about suppression of political activity exhaust the list of serious sources of distrust of the legislative process? Not only may the same case present the Court with substantive issues it feels comfortable addressing and ones it does not, but the sources of distrust of governmental processes also may vary in kind and degree across cases, as does the relative competence of the judiciary. The Court must decide whether and to what extent these potential defects balance in favor of the political branches or the judiciary and must allocate responsiblity accordingly.

The comparative institutional analysis I envisage has three fundamental features, which can be set out here and explored as the article proceeds:

(1) Courts and legislatures differ in their capacities to solve substantive questions, and the degree and kind of these differences can vary significantly.

(2) The relative difficulty of various substantive questions arises from social and political realities too varied and subtle to be adequately captured in the broad analytical categories, such as substance and process or principle and policy, employed by many constitutional scholars. In general, such simple bifurcations are inferior to an approach that can more naturally accommodate the gradations in and interplay among these underlying factors.

(3) Although a role for courts in our constitutional system might be based on the identification of flaws in the legislative process, thereby overcoming the presumption of constitutionality traditionally accorded the more democratic institutions, identification of a legislative flaw should not be conclusive; the 
analysis must be comparative. The legislature has defects and advantages relative to the judiciary. Whether and to what extent the court takes the decision from the legislature should reflect this reality.

The approach offered here can be used for both descriptive or positive, and prescriptive or normative, purposes. ${ }^{1}$ Lawyers defending clients who have been harmed by the action of the government are interested principally in the former. They want to know the extent to which the courts will provide protection for their clients-the likelihood that the courts will invalidate the governmental action-and they want to know what factors, when emphasized, will increase that likelihood. The scholars whose perceptions of institutional analysis are considered here are interested principally in the latter. They wish to know whether the courts' decisions are correct and how they might be changed for the better. This article argues that institutional considerations play a central role in constitutional decisions and that they should be a central feature of any analysis of constitutional law whether descriptive or prescriptive.

It should not be supposed, however, that the analysis I propose is straightforward or obvious. Because we lack a well-developed discipline of comparative institutional analysis, it is difficult to determine which factors are important and which balance among them is appropriate in a given setting. The social sciences literature includes many studies of institutions that are efforts at comparative institutional analysis and, thus, provide theoretical insight. ${ }^{2}$ Similarly, the insights, intuitions, and impressions of law-

1 For a consideration of the goals of legal analysis identified by terms such as "positive" and "normative," see Komesar, In Search of a General Approach to Legal Analysis: A Comparative Institutional Alternative, 79 Mrch. L. Rev. 1350, 1354-56 (1981).

2 In political science, there are examples of extensive inquiry into institutions. These include such works as Leonard White's examination of the history of the federal executive departments, see L. White, The Federalists: A Study in Administrative History, 1789 1801 (1948); L. White, The Jefrersonians: A Study in Administrative History, 1801-1829 (1951); L. White, The Jacksonians: A StUdy In Administrative History, 1829-1861 (1954); L. White, The Republican Era: A Study in Administrative History, 1869-1901 (1958), and Theodore Lowi's classic critique of pluralist theory, see T. Lowi, The END of Liberalism (1969); see also R. Dahl \& C. Lindblom, Politics, Economics and Welrare (1953). The legal historians Lawrence Friedman and Willard Hurst have examined the evolution of the law through its institutional features. See L. Friedman, A History of American Law (1973); J.W. Hurst, Dealing With Statutes (1982) [hereinafter cited as J.W. Hurst, Statutes]; J.W. Hurst, The Growth of American LAW (1950). Willard Hurst's Dealing With Statutes attempts to understand the legislative process by emphasizing its distinct institutional character. J.W. HurST, STATUTES, supra, at 2-8. Economists have also offered theoretical insights about institutions-even nonmarket ones. For a summary of economic analysis of public 
yers, judges, and legal scholars provide rich information. The challenge remains to construct an analytical framework that can integrate the two. While even the simple institutional analysis we can muster at present provides important insights, the primitive nature of our analytical tools makes them as yet inadequate to mine fully the complexity and richness of institutional choice. ${ }^{3}$

My purpose in this article is to promote an intellectual paradigm useful in organizing and ordering the vast range of potential considerations that confront the student of constitutional law. I show that the paradigm provides valuable insights about important cases and issues, and that failure to employ it fully has left significant gaps in prominent constitutional theories. I hope that the applications presented here and my critique of other approaches combine to provide at least a strong case for the value of the paradigm's further refinement and testing-an enterprise I want to convince others to join.

The first section of the article sketches the approach I propose and provides examples of its application. The remainder provides a critique of the way institutional comparison is treated in several prominent existing approaches to constitutional law. I begin with the approach of John Hart Ely, which emphasizes the role of malfunction in the democratic process as a means for determining the proper scope of judicial review. I then turn to the approaches of Harry Wellington and Michael Perry, whose institutional analyses place heavy emphasis on the powers of judicial reasoning and neutrality. Finally, I consider the approaches of Laurence Tribe and Raoul Berger, which deal with institutional analysis by limiting its relevance. 4

sector behavior, see D. Mueller, Public Choice (1979).

3 The approach I suggest has a limit apart from the present inadequacy of the analytical tools. As I have pointed out elsewhere, a comparative institutional approach is, by its nature, incomplete. Komesar, supra note 1, at 1353. It is not possible to perform a complete analysis without establishing some conception of the goal or goals that the institutions are to achieve. To use a rough metaphor, it is not possible to evaluate the choice of tools without knowing the task; a hammer is not always superior to a screwdriver. I shall argue in the body of this article that an analysis based solely on such considerations is basically incomplete, but an analysis that denies any validity to such considerations is also incomplete.

It is my belief that a study of variation in institutional capacity will yield more by way of description and explanation of constitutional decisionmaking than will a study of variation in goals or ideologies. That belief, of course, can be tested only in future applications. In this article, I argue only that the institutional component plays an essential role in constitutional analysis.

- Although I make no claim to survey all existing approaches to constitutional law, one omission deserves special note since it is a prominent example of institutional analysis. In his work, Judicial Review and the National Political Process (1980), Dean Jesse Choper 


\section{An Overview of the Comparative Institutional Approach}

This section discusses the basic institutions of government and the principal distinctions among them, and examines various concepts of institutional malfunction. The discussion then turns to a series of issues in constitutional law in an effort to suggest the proper contours of a serious comparative institutional analysis; my starting point in examining these issues is the political question doctrine, which focuses on the limits of judicial competence. The section concludes with an examination of a number of cases arising in different contexts-cases in which the Court, in profound doubt about the validity of action by the relevant political branch, has been confronted simultaneously with the limits of judicial ability. The issues of constitutional law I consider throughout this section, are, for the most part, issues of human or individual rights. Because these issues are those most often debated by constitutional theoreticians and, at the same time, those for which institutional comparison initially appears least suitable, they provide a demanding arena in which to test the validity of a comparative institutional approach.

argues that the dynamics of the political processes themselves provide an adequate, albeit imperfect, means for resolving most issues associated with federalism and separation of powers and that the Supreme Court would be wise to turn its attention and resources away from these issues and toward individual rights. See J. CHOPER, Judicial REVIEW AND THE National Political Process 169-70 (1980).

Choper's admirable concern for the workings of the political process, his rich descriptions of that process, and his recognition of the central importance of allocating scarce judicial resources reveal a basic emphasis on institutional attributes. But he leaves the knottiest institutional issues in constitutional law untouched. Although he calls for a greater allocation of judicial resources to the issues of individual rights, he gives us little conceptual guidance on how to determine which social questions are to be addressed by the judiciary as issues of individual rights and to what extent. All legislation or public sector action affects individuals, and virtually all such activity affects some individuals detrimentally.

A court advised to turn from federalism and separation of powers to individual rights will still be left to face the most basic and difficult institutional questions. It must still determine which of the vast range of social issues will receive its attention and, more importantly, the degree of that attention. Indeed, given the number of instances in which it is likely that severe distrust of the political process will be accompanied by strains on judicial ability, federalism and separation of powers may often be optimal albeit indirect methods of dealing with individual rights issues. Thus, the judiciary, faced with the quandary of severe distrust of the political process and severe discomfort with its own abilities, may move to intermediate solutions that involve the search for the least bad political actors or a delay followed by redecision by another political entity. See infra note 30; text accompanying notes 31-33. These solutions often have the distinct flavor of federalism or separation of powers. 


\section{A. The Basic Institutions}

For my purposes, the primary institutional distinction to be made is between the judiciary and the political branches ${ }^{\mathbf{b}}$ of government that produce the state action under review. ${ }^{6}$ Perhaps the most important difference between the political branches and the federal judiciary is in the job security of the principal decisionmakers. Federal judges have life tenure. ${ }^{7}$ Legislators and executives serve for shorter terms, ranging from two to six years at the federal level. ${ }^{8}$ Legislators and executives interested in retaining office must be attuned to the desires of at least the politically active voters in their districts. Judges, by contrast, need not.

The decisional structure of the political branches also differs significantly from that of the courts. The political branches, for example, have significantly greater flexibility in determining the agenda of social issues they will address. ${ }^{9}$ Courts can only address

S The term "political branches" is used throughout this article as a short-hand for the non-judicial branches of government that produce the official action reviewed by the judiciary. Use of the term "political branches" is not meant to signify either that the judiciary is not a branch of government or that it is completely divorced from all political considerations. It is a commonly used term, employed here for expositional convenience.

- We shall subsequently see that this distinction begins to break down in cases where a judiciary, facing strains on its own capacity, aligns itself with one or another of the political branches in the resolution of a particular issue. For a discussion of one such case, see the analysis of Hampton v. Mow Sun Wong, 426 U.S. 88 (1976), infra notes 45-63 and accompanying text. The broad distinction suggested here, however, provides a valid starting point.

${ }^{7}$ Life tenure is granted to federal article III judges. U.S. Const. art. III, $\$ 1$ ("Judges ... shall hold their Offices during good Behavior ...."). Federal administrative judges have shorter terms determined by statute. See, e.g., 26 U.S.C. \$ 7443(e) (15-year term for Tax Court judges). The terms of state supreme court judges vary with jurisdictions from a high of 14 years in New York, see N.Y. ConsT. art. 6, § 2, to a low of 6 years in Alabama, see ALA. Const. art. VI, $\S 158$. State trial court judges generally serve four to six year terms. See, e.g., Ill. Const. art. 6, § 10 (six-year term); OkLA. Const. art. 7, § 8(a) (four-year term).

- U.S. CoNsT. art. I, \& 2 (congressmen serve two-year terms), §3 (senators serve six-year terms), art. II, § 1 (president serves four-year term).

- This flexibility may vary-at least formally-within the political branches. On the subject of the broad jurisdiction of the legislature, Willard Hurst offers the following comment:

The country's separation of powers tradition assigns an open-door policy to the legislative function. With only narrow exceptions any party may bring any subject into the legislative arena.

This distinctive breadth of legislative jurisdiction stands out by contrast with the limits our tradition has set on approaching other agencies. However broad in total impact, executive or administrative lawmaking depends on statutory delegations which specialize the parties and subject matter with which such agencies may deal. Lawmaking by judges is hedged in by doctrines of standing, justiciability, and precedent. But no formal barriers of standing limit access to a legislature. Anyone who can persuade a legislator to introduce a bill can cause the matter of his concern to be put into the legislative machinery. Generally the legislature is free to make its own judgments of 
social issues brought to them by litigants. The political branches also have more flexibility and resources to investigate the social issues they address. In an adversarial judicial system, the litigants are the primary sources of information, and courts are largely limited to information provided by advocates. Further, the courts face formal restrictions on the disposition of issues brought before them. They cannot, without justification, ignore a matter properly before them; the legislature and executive can. A court's agenda and the amount of attention it must give to an issue are also affected by the willingness or reluctance of litigants to settle the given case.

These differences in flexibility and scope are related to and underscored by a power traditionally held by the legislature-the power to spend. By the exercise of this power, legislatures control the operational scale of all branches of government, including the judiciary. On the federal level, Congress can and has increased significantly the scale of both the legislative and the executive processes. A vast array of agencies, bureaus, commissions, committees, and staffs is now responsible to the Congress or the President. These entities aid in making government policy or make it directly themselves. There has been no comparable increase in spending on the federal judiciary, leading to a substantial divergence between the relative expenditures on the federal judiciary and on the political branches. ${ }^{30}$

what matters are suitable for legislative consideration. And the novelty of a proposal for legislation, or the fact that it will change prior common or statute law, raises no legal barrier to its adoption.

J.W. HURST, STATUTES, supra note 2, at 2-3 (footnotes omitted).

10 In 1980 the total expenditure on the federal judiciary was about $\$ 564$ million. See Fiscal Service, Bureau of Government Financial Operations, U.S. Dep't of the TreaSURy, Doc. No. 3281, Combined Statement of Recerpts, Expenditures and Balances op THE United States Government 13 (1980) [hereinafter cited as 1980 U.S. Accounts]. While the statements of accounts in 1980 U.S. AccounTs make it difficult to calculate administrative costs for Congress, the executive, and the federal administrative agencies, a careful estimate yields a figure in excess of $\$ 94$ billion-over 160 times the budget for the judiciary. See $i d$. at $110-24,132-508$. In 1925 , the analogous figures were approximately $\$ 19$ million for the judiciary, see Division of BookkeEping and Warrants, U.S. Dep'T of TrEasury, Doc. No. 2966, Combined Statement of the Receipts and Disbursements Balances, etc. of the UNITED STATES 131 (1925) [hereinafter cited as 1925 U.S. AccounTs], and \$424 million for the political branches, see id. at 40-253, the latter less than 23 times the size of the former. In other words, the administrative budget of the political branches had grown more than seven times as fast as the budget of the judiciary.

Although the most dramatic source of the difference is the growth in administrative agency budgets, compare 1980 U.S. AccounTs, supra, at 140-502, with 1925 U.S. AccounTs, supra, at 49-253, even the figures for Congress and the executive proper dwarf those for the courts. In 1980, that figure was over $\$ 1.25$ billion, or more than twice the judicial budget. 
These generalizations about important operational differences between the judiciary and the political branches provide the framework for analyzing constitutional issues and cases discussed later in this section. Narrower, more intensive studies of particular constitutional issues may call for consideration of other institutions or for a more detailed description of the attributes of these institutions. The foregoing treatment, however, will suffice for present purposes.

\section{B. Political Malfunction and Judicial Competence}

What features of the decisionmaking process of the political branches-here called "defects" or "malfunctions"-cause or should cause the courts to distrust the decisions of these branches? ${ }^{11}$

There is no universally accepted definition of political malfunction, but it is possible to offer something of a taxonomy that reflects and expands upon conceptions presented in the constitutional law literature. First, the ways in which the electorate is defined can give rise to distrust of legislative decisionmaking. Often, the interests of a person or group are affected by legislation on which that person or group has no formal say, no vote. Decisions made by states and localities, for example, can affect people who do not live in and, therefore, have no vote in that jurisdiction. There may also be residents of a jurisdiction who have no vote at all. For most of our history, women did not have the vote; blacks brought to this nation as slaves did not have the vote on a formal basis until several years after emancipation and were denied it in

See 1980 U.S. AccounTs, supra, at 110-24, 132-38. In 1925, the budget for the federal judiciary was actually greater than the administrative budget for Congress and the executive by approximately $30 \%$. Compare 1925 U.S. AccounTs, supra, at 131, with id. at 47-48. In the 55-year period, the budget for Congress and the Executive increased almost three times faster than that of the judiciary.

11 Beginning the case for judicial review with a search for defects in the political process is more than an expositional convenience. It is consistent with the traditional presumption that determinations of the public good made by the legislature are consitutionally valid, because it envisions a need for some showing that there is a problem with the legislative process before the courts consider invalidating the legislature's determination.

This presumption of constitutionality is as old as American constitutional review, see, e.g., Currie, The Constitution in the Supreme Court: 1789-1801, 48 U. CHI. L. REv. 819, 851 (1981) (discussing Mossman v. Higginson, 4 U.S. (4 Dall.) 12 (1800)), and has been rephrased and refurbished at several stages. In an article commonly viewed by constitutional scholars as the beginning of modern constitutional theory, James Bradley Thayer reviewed the meaning of the concept of the presumption of constitutionality and made it the cornerstone for his own theory of the role of judicial review. See Thayer, The Origin and Scope of the American Doctrine of Constitutional Law, 7 Harv. L. REv. 129 (1893). 
practice long after that; minors and aliens do not now have the vote. Thus, even if we were completely sanguine about the ability of legislators to reflect the will of the voting public and were convinced that the public will necessarily defines the public good, a system in which not all the public voted would remain problematic. ${ }^{12}$ Of course, this conception of malfunction is a simplification. Many who do not have the vote are represented indirectly by those who do. We have usually assumed that the interests of children are represented by concerned adult parents. On some matters, the interests of women may have been represented by voting males-husbands, fathers, brothers and so on. Aliens may be represented by citizens who recall their own backgrounds and empathize with the aliens. Yet, whatever the qualifications, formal exclusion from the political process seems a likely source of distrust that would and should attract the interest of a reviewing court.

Second, if the formal exclusion of certain groups from the political process can provide a basis for distrust of the legislative process, one need not take a large conceptual step to envision de facto exclusions that can trigger similar reactions in reviewing courts. Certain groups, enfranchised, nevertheless may have their interests underrepresented in the legislative process. ${ }^{13}$ The classic examples

12 Throughout this article, I tend to equate representation of the desires of the populace with the social good. It is a convenient and frequently employed assumption though quite obviously it is not universally accepted. The definition is consistent with a utilitarian conception of good. It is also consistent with the Rawls's notion of public desires generated in a neutral state, since a person in this neutral state would have incentives to decide what is best for everyone because he himself might be anyone. See J. RAwLs, A THEORY of JusTICE 164-66 (1971).

I do not, by virtue of this assumption, mean to subscribe to any particular definition of the good. I only employ this assumption here to demonstrate the range of institutional questions raised by one common definition of the good. I develop the same theme for other conceptions of the good infra text accompanying notes 187-99. As I have indicated elsewhere, better development of notions of social good would aid the development of the attendant institutional analyses. Komesar, supra note 1, at 1391. The outcomes of institutional analyses associated with existing conceptions of social good are, of course, subject to change as we develop better conceptions of either institutions or social good.

is If adequate representation is regarded as a means to the achievement of some social goal, then the choice of goal will affect the assessment of the adequacy of the representation or of defects in the political process in general. For example, if one were to focus on efficient resource allocation as a social goal, one could identify specific corresponding imperfections in the the political process that would impede its achievement. For a description of the "public choice" literature of economics, wherein these imperfections are examined, see D. Muelize, Public Chorce (1979). Elsewhere I have offered two polar models of political process and discussed their imperfections as a means for selecting among allocative preferences. See Komesar, Housing, Zoning, and the Public Interest, in B. WeISBRod, J. HaNdLER \& N. Komesar, PUblic InTERest LaW-AN Economic and Institutional ANalysis 218, 221-23 (1978). 
of such groups recognized in modern constitutional law are racial, ethnic, and religious minorities. In the famous footnote in United States v. Carolene Products Co. ${ }^{14}$ the Court pointed to legislation imposing distinct disadvantages on "discrete and insular minorities" as an instance in which the strong presumption of constitutionality might not apply. In subsequent decades, the Court has shown special concern when legislation adversely affected racial, ethnic, and religious minorities. The perceived mechanics of underrepresentation, like the term "discrete and insular," remain vague, but it seems clear that concerns about political powerlessness play a role in raising the Court's suspicions.

Third, though the formal exclusion of relevant interests and the underrepresentation of traditional minorities are the most frequently cited examples of political malfunction, the judicial and scholarly commentary reflects others as well. The Carolene Products footnote, for example, also expressed concern about legislative attempts to control elements of the political process such as voting, speech, and assembly. It has been suggested that such concern reflects the judiciary's suspicion that political incumbents might be tempted to employ their offices to maximize their incumbency by silencing and defusing opposition. ${ }^{16}$

Fourth, beyond the confines of modern constitutional commentary, there are other broad sources of distrust with significant historical and theoretical pedigree. One notices, for example, worry about the maltreatment of the majority by concentrated special interests. A long history of concern about the overrepresentation of some minorities may, indeed, be as strong a part of our tradition as is the concern about the underrepresentation of other minorities. ${ }^{16}$ And even within the confines of concern about minority underrepresentation, there lurks a broader sense of concern for the failure to represent adequately a numerical minority whose members have very high stakes in the resolution of a particular question against a numerical majority whose members have very low stakes. $^{17}$

14304 U.S. 144, 152 n.4 (1938). The text of the note appears infra note 143.

is See J. Ely, Democracy AND DisTrust 75-77 (1980). Whether and to what extent, this desire by incumbents to perpetuate their incumbency actually constitutes a separate source of political imperfection is considered infra note 141 .

36 I explore this theme and its pedigree in my discussion of Ely and the Carolene Products footnote infra notes 143-60 and accompanying text.

17 For a fuller examination of the problem of disproportionate stakes in the resolution of a particular question, see Komesar, supra note 13, at 223-29. While this theme is most often addressed in discussions premised on the contention that the prime social goal is the 
This list is obviously neither complete nor precise. ${ }^{18}$ More rigorous definition of political malfunction requires a simple and accepted conception of social good, or at least a better defined range of such conceptions, that could then be employed to define a range of potential political malfunctions. Although attempts to comb the literature for such conceptions and to generate a series of political models to fit them are best left for studies of specific areas of constitutional law, the sections that follow will expand upon this list of political malfunctions and will attempt to specify their theoretical underpinnings.

No matter how complete our description of the set of political malfunctions, however, we would still lack a complete institutional basis for understanding and evaluating constitutional decisions. A recognition that the political process is imperfect and at times severely so provides only one component of a thorough institutional analysis. A court that normally harbors a strong presumption in favor of legislative supremacy may be willing to reconsider that presumption in the face of severe political malfunction, but it would not and should not abandon the presumption unless in the given setting it can offer an alternative superior to the defective legislative process. In other words, the judiciary must consider its own capacity for evaluating the social issue posed by the legislation under review in a given case. For example, a court must consider its "physical" resources-in particular, the number of available

promotion of total public welfare or the efficient allocation of resources, it might well have a place when other social goals are viewed as preeminent. Both the analysis of special interests, which concerns the overrepresentation of concentrated minorities, and the analysis of intensity bias, which concerns the underrepresentation of dispersed majorities, deserve greater attention in the analysis of a wide variety of social goals. Again, the failure carefully to define these goals handicaps the institutional analysts' attempts to suggest their institutional implications.

${ }^{18}$ For example, some scholars have suggested that the legislative process may suffer from a form of inertia that severely delays the repeal or amendment of legislation that is no longer socially desirable. The "remand" function of judicial review suggested by Bickel and Wellington appears to reflect this perception. See Bickel \& Wellington, Legislative Purpose and the Judicial Process: The Lincoln Mills Case, 71 HARv. L. REv. 1, 22-35 (1957). Bickel further developed his analysis of the remand function of judicial review in A. Brckel, THE Least DANGerous Branch 165-66 (1962). Both the remand function and the problem of legislative inertia play central positions in Calabresi's recent work on the role of the judiciary in statutory review. See G. Calabresi, A Common Law for the Age of Statutes 120-24 (1982).

None of the authors spells out carefully his explanation for why the legislature is inert in one instance and not in others. This legislative malfunction may, in fact, be no more than a manifestation of others we have noted, such as the underrepresentation or overrepresentation of minorities. When, and to what extent, under- or over-representation may occur is explored in Komesar, supra note 13, at 221-29. 
judges. Recently, a number of scholars have pointed out that this century has seen an increase in the output of the legislative process. ${ }^{19}$ The political branches-legislative, executive and administrative-have grown immensely. The judiciary has not grown nearly so much over the same period. ${ }^{20}$

Each claim of constitutional invalidity presents a different set of demands on the resources of the judiciary. Cases will vary in the number and complexity of judicial determinations needed for their complete resolution. When the Court declares a right, it must face the task of defining that right and the associated remedy. In some instances, it can define the right in clear terms and offer a remedy that involves little continuing judicial action. Other instances require the Court to define a right in general terms, and either clarify it gradually in future litigation or provide a remedy that involves continuing judicial supervision-even continuing appellate supervision.

By way of illustration, we can compare the Court's decisions in Roe v. Wade ${ }^{21}$ and Brown v. Board of Education. ${ }^{22}$ The first defined the right to seek an abortion. The second defined the right to attend public schools without regard to race. Both cases involve controversial instances of judicial intervention; yet, the two differ in the Court's general approach to defining the rights and remedies involved. In Roe, the Court spelled out the right to abortion in relatively specific terms. It split the period of pregnancy into trimesters and defined different rights for pregnant women and the state in reference to the different trimesters. ${ }^{23}$ Violations of the rights described were remedied by invalidating the offending restrictions. ${ }^{24}$ In Brown, the Court invalidated racial restrictions on school attendance, ${ }^{25}$ but it declined to specify the appropriate form of remedy. ${ }^{26}$ In subsequent cases, the Court has struggled in its efforts to define the rights and remedies associated with school desegregation. ${ }^{27}$ Its efforts have consistently produced standards re-

19 See, e.g., G. CALABRESI, supra note 18, at 1-7; J.W. Hurst, STATuTEs, supra note 2, at 14 (1982).

20 See supra note 10.

21410 U.S. 113 (1973).

22347 U.S. 483 (1954).

23 See Roe v. Wade, 410 U.S. at 162-65.

24 See id. at 166.

25 See Brown v. Board of Educ., 347 U.S. at 495.

28 See id. at 495-96.

${ }^{27}$ See, e.g., Green v. County School Bd., 391 U.S. 430 (1968); Goss v. Board of Educ., 373 U.S. 683 (1963). 
quiring a substantial continuing role for the lower federal courts. ${ }^{28}$

I am not suggesting that the abortion issue was better resolved than the school desegregation issue because its resolution has proven easier to administer. The reaction of some state and local officials to the Brown decision showed a determination to obstruct desegregation. The Court had strong basis to infer that racial segregation would be achieved by other means if the Court were merely to invalidate the legislation that prohibited integration. Neither am I suggesting that Brown was the more questionable decision because its implementation has required more judicial resources. The effect on judicial resources is only one of many considerations associated with the capacity of the judiciary, and the judiciary is only one of the institutions to be considered. ${ }^{29}$ Rather, I am arguing that, if we assume the remedies in Brown and Roe were equally appropriate for their given settings, the school desegregation issue posed a much greater potential for requiring a continuing outlay of judicial resources and that this potentially greater cost was a relevant consideration in the calculus of institutional comparison. Had the Court's level of distrust of the legislative process not been so great, this consideration might have changed the outcome in Brown..$^{30}$

${ }^{28}$ See, e.g., Swann v. Charlotte-Mecklenburg Bd. of Educ., 402 U.S. 1, 7-8 (1971); Brown v. Board of Educ., 349 U.S. 294, 299-300 (1955).

${ }^{29}$ The more specific remedy proposed in Roe is by no means ideal. The arbitrary nature of the trimester approach has been criticized by both opponents and proponents of a broadbased constitutional right to abortion. See Akron v. Akron Center for Reproductive Health, Inc., 103 S. Ct. 2481, 2508 (1983) (O'Connor, J., dissenting); Lynn, Women's Reproductive Rights, 7 WomEN's LAW RPTR. 223, 226 (1982).

so So brief a treatment of these important cases unfortunately risks misunderstanding. That strain on judicial resources is an important consideration does not necessitate that the judiciary would or should be less willing to provide active review of a political decision. Faced with serious doubts about the political process, along with strains on its resources, the Court might well respond with a sweeping declaration that all laws of a particular type are invalid. Both sweeping validations and sweeping invalidations husband the Court's resources. I explore this theme further infra text accompanying notes 36-40.

In response to strains on its resources, the judiciary may also attempt innovative remedies such as looking for help from within the political process or seeking to replicate parts of the political process through panels roughly representing the range of community interests. I have come to call the former the "trusty buddy" approach. One can see it at work, for example, in Justice Brennan's concurring opinion in United Jewish Orgs. v. Carey, 430 U.S. 144, 175 (1977) (Brennan, J., concurring), where "considerable deference" is accorded the judgment of the Attorney General in his capacity as "champion of the interests of minority voters" under $\S 5$ of the Voting Rights Act, 42 U.S.C. $\S 1973 c$ (1982). One can also see it in the Court's willingness to define the scope of statutory violations more broadly than similar constitutional violations. In Washington v. Davis, 426 U.S. 229, 246-48 (1976), for example, the Court enunciated an "intent" test for racial classifications that violate the equal protection clause of the fourteenth amendment (or the equal protection aspect of the fifth amend- 
The degree of strain on judicial resources is also related to the relative competence of the judiciary to resolve the particular social issue involved in a given controversy. The more uncertain the judiciary is about how to resolve the issue, and the more it needs to learn about the subject matter, the greater will be its inclination to adopt a resolution couched in flexible terms to be delimited in subsequent litigation. In the narrowest sense, judicial competence is determined by the training and background of judges. By virtue of their experience, for example, judges have a degree of special competence to decide questions of procedural due process or criminal procedure. Where the legislation under review affects judicial procedure or quasi-judicial, administrative procedure, judges feel more confident, probably with justification, in their ability to dispose accurately and efficiently of the issue than where the legislation concerns subjects farther from their common experience.

But the concern with judicial competence goes beyond how judges are trained or what specific information they have. Judges are actors in a larger judicial process. The information they receive is, to a significant degree, that produced by the particular litigants before them; judges have few formal channels for independent investigation. More important, the judicial system is poorly placed to receive information on the desires and preferences of the public or any given part of it.

It is one thing to make a list of considerations or interests; it is quite another to determine the weights to be given conflicting interests in a given context. Even if the issue before the court is one of procedural due process, and even if one assumes that procedures serve only instrumental purposes, ${ }^{31}$ resolution of the issue cannot

ment due process clause) while retaining the broader "impact" test for violations of civil rights statutes. See Griggs v. Duke Power Co., 401 U.S. 424, 429-33 (1971). One sees the effort to replicate the political process through the use of a representative panel in the approach of the district court in Chance v. Board of Examiners, 330 F. Supp. 203 (S.D.N.Y. 1971), discussed in M. Rebell \& A. Block, Educational Policy Making and the Courts: An Empirical Study of Judicial Activism 75-122 (1982). The role of the panel as a replication of the political process is a theme advanced in Bill Clune's book review of M. REBeLL AND A. Block, supra. See Clune, Book Review, 93 Yale L.J 763, 774-75 (1984).

The point of recognizing the constraints imposed on the judiciary by the limits of its physical resources is simply that the judiciary must consider those constraints in determining how it will respond to a given social issue. The Court, and the judiciary in general, may be physically incapable of playing an active role in more than a limited number of social controversies that require significant and continuing outlays of judicial resources. But the existence of this constraint should begin an analysis of judicial review, not conclude it.

${ }^{31}$ See Matthews v. Eldridge, 424 U.S. 319, 334-35 (1976) (key to procedural due process is whether the safeguards adequately decrease the risk of erroneous deprivation). There are strong arguments that procedures should exist not only to serve the instrumental purpose of 
ignore the basic desires and perceptions of the populace about the trade-off between accuracy or fairness and other ends on which society might expend resources. The determination of such trade-offs is the sort of basic choice commonly left to such diviners of the aggregate popular perception as the legislature or the market. I do not mean that the judiciary is always inferior at making these choices-that judgment depends upon a consideration of the relative efficacy of each of the available institutions in the given context. The point is that access to information broadly defined is an important element in any assessment of judicial competence.

\section{The Political Question Doctrine}

Under the rubric "political question doctrine," the Court has declared that certain constitutional issues are nonjusticiable because they are exclusively the responsibility of the "political" branches of government. Given what both the Court ${ }^{32}$ and com-

greater accuracy but also to acknowledge the dignity and individuality of those who must deal with governmental bureaucracy. See, e.g., Mashaw, Administrative Due Process: The Quest for a Dignitary Theory, 61 B.U.L. REv. 885, 885-922 (1981). When such considerations are included, the need for inquiry into the public perception about the trade-off between accuracy and other ends in order to decide even a procedural issue becomes still more pressing.

s2 In Baker v. Carr, 369 U.S. 186 (1962), the Court summarized the factors that are likely to make an issue nonjusticiable under the doctrine:

It is apparent that several formulations which vary slightly according to the settings in which the questions arise may describe a political question, although each has one or more elements which identify it as essentially a function of the separation of powers. Prominent on the surface of any case held to involve a political question is found a textually demonstrable constitutional commitment of the issue to a coordinate political department; or a lack of judicially discoverable and manageable standards for resolving it; or the impossibility of deciding without an initial policy determination of a kind clearly for nonjudicial discretion; or the impossibility of a court's undertaking independent resolution without expressing lack of the respect due coordinate branches of government; or an unusual need for unquestioning adherence to a political decision already made; or the potentiality of embarrassment from multifarious pronouncements by various departments on one question.

Id. at 217.

The first two nonpositivistic factors stand out as concerns about the ability of the judiciary: "a lack of judicially discoverable and manageable standards for resolving [the case]; or the impossibility of deciding without an initial policy determination of a kind clearly for nonjudicial discretion . . . ." Even the elements that follow are institutional. They reflect Alexander Bickel's notion of protecting the judiciary's "institutional capital," by which Bickel meant the ability of the judiciary to command respect for its decisions from the other branches of government and from the populace as a whole. Without a sufficient level of respect, the judiciary, lacking its own executive power, would be virtually impotent. See A. BickeL, supra note 18, at 25-26; see also infra text following note 80 (discussing Korematsu v. United States, 323 U.S. 214 (1944)). 
mentators ${ }^{33}$ have identified as a concern with questions of institutional competence in this area of the Court's jurisprudence, the political question doctrine seems an obvious place to begin an inquiry into judicial competence as an aspect of comparative institutional analysis.

Nearly twenty years ago, Professor Fritz Scharpf, focusing on the political question doctrine, undertook a thoughtful institutional analysis that even today provides useful insights into the meaning and scope of judicial competence. ${ }^{34}$ Early in his article, in a definition of what he calls "functional analysis," Scharpf neatly captures the view that constitutional law often engages questions of institutional abilities and that strains on those abilities can lead to either judicial innovation or judicial restraint:

The term "functional" as used throughout this article refers to the interrelationship between the nature of the task which the Court is performing and the means which it can employ for the performance of this task. If its ordinary means prove inadequate for a particular task, the Court may react either by enlarging its arsenal of means or by limiting the tasks which it will perform. Both reactions will be characterized as functional. ${ }^{35}$

Scharpf identified three attributes of the judiciary that limit its competence especially in political question cases: limitations on access to information; the need for uniformity of decision; and the need to defer to the wider responsibility of the political branches. ${ }^{36}$ One may observe these attributes at work in the foreign relations cases, which Scharpf and others take as paradigmatic of the political question doctrine.

The conduct of foreign affairs requires flexibility, secrecy, expedition and special expertise. The Court's decisionmaking, however, is deliberate and exposed. The judiciary has no separate means of access to foreign intelligence, and the adversarial process affords little opportunity for providing it. Any attempt to break the government's hold on foreign intelligence raises the possibility

ss Laurence Tribe, who is otherwise critical of institutional anaylsis, see infra notes 186-200 and accompanying text, stresses the role of judicial competence in the political question doctrine in his treatise. Tribe's treatise also summarizes other commentary on the political question doctrine. See L. Tribe, Ambrican Constitutional Law 71-79 (1978).

34 Scharpf, Judicial Review and the Political Question: A Functional Analysis, 75 YALE L.J. 517 (1966).

${ }^{36}$ Id. at $523 \mathrm{n} .21$.

se Id. at $567-83$. 
of exposing sensitive information, a risk the Court has little way of assessing in advance. Even if the judiciary can acquire information germane to the foreign relations issue to be addressed in the case before it, it might well be unable to understand the context in which that issue arises, since the issue might interact with other issues as to which the Court has neither control nor cognizance beyond a sense of their existence. Given these limitations, the judiciary is forced to be concerned that it may be doing damage by exposing sensitive information, reducing necessary flexibility, or otherwise producing undesirable results.

Scharpf recognized that the Court could respond to these limitations in several ways other than the abstention required by the political question doctrine. For example, the Court might use such procedural or jurisdictional responses as "standing" or "ripeness" to delay its decision in an effort to clarify the issues and facts. ${ }^{37}$ Yet Scharpf recognized that this response would not be available in every case since there would be instances in which such techniques simply could not provide the Court with the information necessary to gain control over the particulars. Even here, Scharpf suggested, the Court could avoid abstaining by adopting a sweeping or "absolute" substantive solution: "When resolution of the issue as such would require information which is generally difficult to obtain, the Court may redefine the substantive standards in the 'absolute' or 'abstract' terms of an unqualified grant of power or of an unqualified limitation upon power, whichever appears more desirable to the Court." 38 Scharpf argued that such an absolute response would be less likely where the lack of information was so severe that the Court could have no basis for presuming that its sweeping response would be even "a tenable and workable accomodation of the interests at stake." 39 In that instance, abstention seems the preferable alternative.

Yet, as Scharpf recognized, his functional analysis, with its focus on degrees of judicial competence, was somehow incomplete. Scharpf understood well that the judicial limitations he had identified existed to varying degrees not only where foreign affairs were concerned, but also in other cases, many of which fell well outside

${ }^{37}$ See id. at 519-23. Here Scharpf was explicitly reflecting the influence of Bickel's concept of "passive virtues." Compare id. (agreeing with Bickel on function of judicial review but arguing that political question doctrine nonetheless is not fully justified), with A. BickEL, supra note 18, at 11-98 (discussing the nature and justification of judicial review).

${ }^{38}$ Scharpf, supra note 34 , at 567.

so Id. 
even the broadest reading of the political question doctrine. War and national security cases, Scharpf argued, raised functional difficulties of the same order as foreign relations cases, and yet were only tangentially implicated in the political question doctrine.$^{40} \mathrm{He}$ explained this difference by noting that war and national security cases often involve important human rights or separation of powers questions." In fact, where "important individual rights" were involved, Scharpf noted that even foreign relations issues sometimes escaped the political question doctrine. ${ }^{42}$

This "individual rights" exception has been chronicled by others, ${ }^{43}$ usually with citation to Scharpf. But to identify such an exception is really just to beg the question of the true scope of the political question doctrine. Although Scharpf dug behind the standard phrases to isolate functional factors that explained some of the apparent inconsistencies in the political question doctrine, he stopped too soon. Most constitutional challenges to action by the political branches, including those declared nonjusticiable under the political question doctrine, involve claims of serious, detrimental effects upon individuals. It is of little help to define the limits of the political question doctrine by reference to individual rights without having defined the category "individual rights"-something that Scharpf does not attempt.

Scharpf's analysis fails to compare institutions. He did not extend his functional analysis to the political branches whose action the Court reviews. In looking at the judiciary, Scharpf was sensitive not only to the identification of functional problems, but also to the various ways (e.g., abstention, "absolute" solutions) in which the Court might cope with those problems in particular cases. $\mathrm{He}$ did not, however, give parallel treatment to the political branches whose decisions are in question. He made only vague allusions to the corresponding advantages of the political branches and gave no consideration to the various ways in which those advantages might be given play.

Despite its unbalanced emphasis on only one institution, a problem we shall see in the work of other writers ${ }^{44}$-and its consequent failure to define "important individual rights," Scharpf's es-

$10 \mathrm{Id}$. at $583-84$.

13 Id.

12 Id. at 584.

43 See L. Henkin, Foreign Affairs and the Constitution 494 n.35 (1972); L. Tribe, supra note 33 , at 72 n.1.

*4 See, e.g., infra Part II (discussing John Hart Ely's constitutional theory). 
say stands as a fine and, unfortunately, relatively isolated example of careful and creative institutional analysis. His attempt to define the limitations on the judiciary and his examination of the consequences of those limitations in different legal settings are the best in the constitutional law literature. Recognizing the strength of this beginning, it seems appropriate to focus on the types of cases Scharpf studied-foreign affairs, war, and national security cases-in order to broaden and refine the analysis.

\section{Hampton v. Mow Sun Wong}

In Hampton $v$. Mow Sun Wong, ${ }^{45}$ the Court faced a case combining issues of foreign policy with serious questions of legislative and executive malfunction. The evolution of the case, particularly of the government's position, as well as its resolution reveals the interaction of these institutional forces.

In Hampton, several resident aliens claimed that a long-standing civil service regulation excluding aliens from most federal civil service jobs violated their rights under the fifth amendment. In the lower courts, the government argued first, that the provision served the public interest because certain jobs required the attributes of citizenship and second, that the sweeping exclusion of all aliens from most federal civil services jobs was justified as a matter of administrative efficiency. ${ }^{46}$ Such arguments normally prevail under the weak "rational basis" scrutiny accorded most legislation challenged as violative of equal protection. Typically the government need offer only a plausible general purpose and some connection between that purpose and the statute; even the weakest arguments about administrative convenience usually suffice to satisfy the latter inquiry. ${ }^{47}$

The District Court largely accepted the government's arguments, ${ }^{48}$ but the Ninth Circuit held that rational basis scrutiny was not applicable to the case. ${ }^{49}$ Between the district court and Ninth Circuit decisions in Hampton, the Supreme Court had reiterated, in Sugarman v. Dougall, its position ${ }^{50}$ that alienage is a suspect classification. ${ }^{51}$ While noting that the rationale of Sugarman, a

45426 U.S. 88 (1976).

4 See Mow Sun Wong v. Hampton, 333 F. Supp. 527, 531-32 (N.D. Cal. 1971).

47 See, e.g., Railway Express Agency, Inc. v. New York, 336 U.S. 106, 109-10 (1949).

${ }^{4}$ See Mow Sun Wong v. Hampton, 333 F. Supp. 527, 531-32 (N.D. Cal. 1971).

19 Mow Sun Wong v. Hampton, 500 F.2d 1031, 1037 (9th Cir. 1974).

${ }^{\text {so }}$ See, e.g., Graham v. Richardson, 403 U.S. 365, 372 (1971); Yick Wo v. Hopkins, 118 U.S. 356,369 (1886).

${ }^{51}$ Sugarman v. Dougall, 413 U.S. 634, 641 (1973). The Court in Graham v. Richardson, 
case involving state action, was not squarely applicable in the federal context, ${ }^{52}$ the Ninth Circuit nevertheless found the reasoning of the case instructive, ${ }^{53}$ and accordingly applied strict scrutiny to invalidate the regulation in Hampton. ${ }^{54}$

Following the complete rejection of its administrative efficiency argument below, the government underplayed that argument before the Supreme Court, emphasizing instead the foreign policy implications of the treatment of aliens. In particular, the government argued that the President needed the power to vary the federal employment eligibility of aliens, perhaps even by reference to their countries of origin, in order to give full scope to his treaty-making powers. ${ }^{.5}$ In making this argument to the Court, the government raised the stakes. In the decisions below, reasons to suspect the political process had been identified, the presumption of constitutionality had been weakened, and strict scrutiny had been invoked. Now the government played its best card by identifying a reason to suspect the judicial alternative: the spectre of foreign affairs.

The Hampton Court affirmed the decision below to invalidate the regulation. But it did so on grounds different from those employed by the courts below and, indeed, seemingly different from those the Court had employed for over forty years. ${ }^{56}$ It refused to decide that an exclusion of aliens from civil service employment was invalid per se. The law was declared invalid because the wrong entity was allowed to make the decision. Had the decision to exclude been made by legislation or perhaps even by direct Executive Order, it might well have passed constitutional muster. ${ }^{57}$ But the implementation of foreign policy and basic immigration policy, the Court ruled, could not be left to the discretion of the head of the Civil Service, at least not without a clear indication of such delega-

403 U.S. $365,372-75$, emphasized the political powerlessness of this disenfranchised group. For a discussion of political powerlessness, see supra text following note 11 .

${ }_{32}$ Mow Sun Wong v. Hampton, 500 F.2d 1031, 1036-37 (9th Cir. 1974).

ss Id.

s4 Id. at 1037.

ss They [the government petitioners] argue, for example, that the broad exclusion may facilitate the President's negotiation of treaties with foreign powers by enabling him to offer employment opportunities to citizens of a given foreign country in exchange for reciprocal concessions-an offer he could not make if those aliens were already eligible for federal jobs.

Hampton v. Mow Sun Wong, 426 U.S. at 104.

se See id. at 117-22 (Rehnquist, J., dissenting).

${ }^{57} \mathrm{Id}$. at 116. 
tion by Congress or the executive. ${ }^{58}$

The Court recognized that "the paramount federal power over immigration and naturalization forecloses a simple extension" to the federal context of the equal protection logic barring state attempts to exclude aliens from the state civil service. ${ }^{59}$ Yet, the fact that the exclusion burdened a class which had such a weak political position signaled the need for more than minimal judicial scrutiny. The Court chose to apply this scrutiny, however, not to the provision excluding aliens from civil service jobs, but to the decision to delegate that authority to the civil service. Under normal circumstances, the legislative history, which showed, at worst, a long-term acceptance of the regulation by Congress and the President, ${ }^{60}$ would clearly have been sufficient to find the requisite legislative intent to delegate the decision. But the Court, concluding that these were not normal circumstances, required clearer indications of deliberativeness not only in the evolution of the regulation, but also in the prior delegation of responsibility. ${ }^{61}$

Justice Rehnquist, in dissent, suggested that this was a novel theory, "inexplicably meld[ing] together the concepts of equal protection and procedural and substantive due process." ${ }^{2}$ While the articulated theory, with its inexplicable mix of traditional legal concepts, may have been novel in a doctrinal sense, from an institutional standpoint, it seems both explicable and sensible. As the Court clearly recognized, both the political and judicial processes were strained in this context. The Court was sensitive to the political fragility of the group discriminated against yet was unable either to dismiss out of hand or to take upon itself the foreign policy questions involved. It chose a response that represented a compromise between these considerations by examining carefully the process of decision, a matter more within its competence, even though the particulars of the decision itself were outside its institutional capacity.

I do not suggest that this compromise is the best possible institutional resolution. Since the political weakness of aliens remains a problem whether the decision is left to Congress or the President, the Court may only have delayed the final resolution of

\footnotetext{
${ }^{68}$ Id. at 116.

${ }^{60}$ Id. at 100.

${ }^{\text {Bo }}$ See id. at 105-14.

${ }^{61}$ Id. at 116-17.

${ }^{62}$ Id. at 119 .
} 
the issue. ${ }^{63}$ But however the issue is resolved, it clearly involves difficult and important institutional questions, questions that all the Justices were forced to face whatever their final choices. For the practitioner, the case shows the importance of institutional factors and provides lessons in prediction and strategy. For the evaluator, it highlights important dimensions that must be considered in analyses of the law.

\section{E. Korematsu v. United States}

The institutional configuration in Hampton is not novel. Quite similar elements can be seen in the controversial case of Korematsu $v$. United States, ${ }^{64}$ where the Court addressed the constitutionality of the exclusion of persons of Japanese ancestry from designated areas of the west coast. Korematsu was a native-born American of Japanese ancestry convicted of refusing to obey a military order to leave his home. ${ }^{65}$ The military order had been issued by the regional military commander pursuant to powers granted by Congress and the President.

In upholding the constitutionality of the government action and the associated conviction of the defendant, the majority, in an opinion authored by Justice Black, enunciated the modern equal protection test with its two levels of scrutiny. The Court declared that "all legal restrictions which curtail the civil rights of a single racial group are immediately suspect" and would be subject to "the most rigid scrutiny." show "pressing public necessity." In Korematsu itself, the Court found the existence of such pressing public necessity based on the record presented by the government. The order was issued within

os In this sense, the compromise of the Hampton Court is a form of "remand" to the legislature suggested by Bickel \& Wellington, supra note 18, at 14-35.

In fact, the Court, confronted with subsequent executive action, Exec. Order No. 11,985, 5 C.F.R. $\$ 7.4$ (1984), reprinted in 5 U.S.C. $\$ 3301$ app. at 521 (1982), promulgating the exclusion of aliens from the federal civil service, seems to have avoided the issue to the disadvantage of aliens. See Vergara v. Hampton, 581 F.2d 1281 (7th Cir. 1978), cert. denied 441 U.S. 905 (1979); Jalil v. Campbell, 590 F.2d 1120 (D.C. Cir. 1978). I leave evaluation of this choice as well as the Court's retreat on the treatment of aliens at the state level, see Foley v. Connelie, 435 U.S. 291 (1978), for future work.

ot 323 U.S. 214 (1944).

os Because Korematsu was convicted only of disobeying the exclusion order, the Court did not address the constitutionality of the further order that he report to an "assembly center to be relocated"-most likely to a relocation center, $i d$. at 222 , or, in the phrase of the petitioner explicitly disavowed by the Court, $i d$. at 223 , a concentration camp.

of Id. at 216.

or Id. 
the first year of American involvement in World War II. The government argued that there were disloyal west coast residents who were of Japanese descent, even among those who were American citizens, and that "it was impossible to bring about an immediate segregation of the disloyal from the loyal [citizens]."68 Therefore, it was necessary, the government argued, to confine the movement of persons of Japanese descent, to place a curfew on them, and to order their temporary relocation. In Hirabayashi $v$. United States, ${ }^{69}$ the Court upheld the validity of the curfew, and in Korematsu it upheld the validity of excluding persons of Japanese ancestry from the west coast war area.

Speaking of Korematsu, a prominent modern commentator has noted that, "[i]n retrospect, the Supreme Court's tolerance of the war-time excesses of Congress seems wrong, but in retrospect it is also clear that the Court saw no reasonable alternative to deference." It appears that a majority of the Court did operate as though it believed that it had little alternative. The Court's response was highly deferential to the judgment of "properly constituted military authorities," w1 with the consequence that "rigid scrutiny" was, in fact, very weak. The majority simply accepted the government's assertions that there were disloyal residents of Japanese descent and that these disloyal residents could not be separated expeditiously from the loyal citizens.

Justice Jackson, in dissent, stated the Court's predicament clearly:

I cannot say, from any evidence before me, that the orders of General DeWitt [the military commander who issued the order] were not reasonably expedient military precautions, nor could I say that they were . . . .

The limitation under which courts always will labor in examining the necessity for a military order are illustrated by this case. How does the Court know that these orders have a reasonable basis in necessity? No evidence whatever on that subject has been taken by this or any other court. There is sharp controversy as to the credibility of the DeWitt report. So the Court, having no real evidence before it, has no choice but to accept General DeWitt's own unsworn, self-serving

\footnotetext{
68 Id. at 219.

620 U.S. $81,104-05$ (1943).

70 L. TRIBE, supra note 33 , at 277.

21 323 U.S. at 223.
} 
statement, untested by any cross-examination, that what he did was reasonable. ${ }^{72}$

Yet, faced with an inability to assess independently the conclusions of the military commander, the Court did not have to accept the government's assertions blindly. It could have rejected the commander's report and the government's assertions and made its own determinations about the relevant issues. At least one Justice was willing to do this. While conceding that a very real threat of invasion existed at the time the order was issued, Justice Murphy argued that a sweeping exclusion based on race was not necessary. ${ }^{73}$ He pointed to the experience in England where tribunals had separately assessed the loyalty of over 70,000 German and Austrian aliens and interned only 2,000. ${ }^{74}$ In this connection, Justice Murphy did more than express his opinion as to good policy; he expressed substantial doubt about the integrity and validity of the process that had led to the government's decision. In a few pages, he laid bare the real possibility that the worst sort of racial stereotypes were at work, presenting General DeWitt's attitude toward individuals of Japanese ancestry as essentially racist. ${ }^{75} \mathrm{He}$ presented evidence that pressure for the mass evacuation had been applied by special interest groups concerned with eliminating commercial competition from Japanese-Americans who had had the temerity to undersell white producers. ${ }^{78}$ In short, Justice Murphy presented strong grounds to distrust the political process underlying the relocation decision.

Yet, even with this strong indictment of the governmental process, only Justice Murphy and, on somewhat narrower grounds, Justice Roberts were willing to find the government's action unconstitutional. Congress and the President had been aware of the English experience and rejected such an approach. The decision, moreover, had been made by an experienced military commander in the field. Why should the judgment of a Justice of the Supreme Court be preferred? The majority included Justices Black and Douglas, who were to be strongly associated with the protection of minority rights, and Chief Justice Stone, who had authored the Carolene Products footnote. They were aware of the possible foibles of General DeWitt and the political process. Indeed, the "most

\footnotetext{
72 Id. at 245 (Jackson, J., dissenting).

73 Id. at 241-42 (Murphy, J., dissenting).

74 Id. at 242 n.16 (Murphy, J., dissenting).

$78 \mathrm{Id}$. at 236.

76 Id. at 239 (Murphy, J., dissenting).
} 
rigid scrutiny" they proposed for "suspect classifications"77 suggested that they were uncomfortable with the government's decision. But Korematsu presented the Court with a difficult choice between highly imperfect institutions. Congress, the executive and the military had access to information and the capability to understand its meaning in the context of the war, but they also had shown clear signs of bias in assessing the information and in weighing all the interests involved. ${ }^{78}$ The Court had inferior access to information and inferior understanding of the general context, but it was less subject to popular racial bias and special interests.

Faced with this dilemma, Justice Jackson argued that the Court should refuse to decide the constitutionality of the government's actions and refuse the military access to civil courts to enforce its orders. ${ }^{79} \mathrm{He}$ would, in effect, have declared the issue nonjusticiable on bases closely aligned to the political question doctrine.

All of the opinions in Korematsu, then, focus upon the problem of choosing between two institutions both of whose capacities were in doubt. Indeed, institutional comparison seems explicit in the Justices' analyses of the case. To observe as much, however, is not to argue that the institutional analysis in Korematsu was necessarily unmixed with concerns other than the relative competences of the judiciary and the political branches. ${ }^{80}$

The Korematsu majority was unwilling to substitute the Court's judgment of national security needs for that of the execu-

77 Id. at 216.

${ }^{78}$ It now appears that, in fact, high-ranking government officials from both the War Department and the Justice Department suppressed information concerning the internment of Japanese-American citizens. Information indicating that mass internment was unnecessary and individual loyalty hearings were a feasible alternative apparently was kept from the Supreme Court during the Hirabayashi and Korematsu hearings. See P. InONS, Justice at War: The Story of the Japanese American Internment Cases 199, 201-02, 205, 207, $285,292,317$ (1983).

79 Id. at 243-46 (Jackson, J., dissenting). One should not overestimate the practical significance of such a refusal. Given the resources of the military in this war zone, the courts were not really necessary to it. Korematsu had been taken from his home and placed in a relocation camp without court order.

${ }^{80}$ Neither is it to claim that the institutional analysis in Korematsu conforms to what we have come to expect from later courts. Although the Carolene Products footnote and the Roosevelt Court's decisions revealed some awareness of the plight of racial minorities and some distrust of the treatment accorded such minorities by the political process, see Bixby, The Roosevelt Court, Democratic Ideology, and Minority Rights: Another Look at United States v. Classic, 90 YALE L.J. 741, 743-45 (1981), it is likely that this awareness has grown with time. Thus, the degree to which racial classifications were suspect in the minds of the Justices may well have been different in 1944 than in subsequent applications of the strict scrutiny test first articulated in Korematsu. 
tive and the military. It bears noting, however, that this unwillingness may not have stemmed entirely from the Court's assessment of its relative incompetence. In wartime, public support for the political branches is unusually strong and that support is all too frequently fueled by xenophobia. A Court already uncertain of the underlying facts and of its ability to substitute its decision for that of the political branches may have been all the more concerned when the case raised the possibility of a confrontation with a wartime Congress and executive. Apart from threats of impeachment or the possibility of maneuvers like court-packing, wartime poses the greater threat that the political branches will simply ignore the Court's decisions, thereby revealing the Court's impotence when stripped of support from the political branches. ${ }^{81}$

The discrepancy between the Justices' perception of the need to protect racial minorities and the actual need, and the Justices' fears of confrontation with the political branches, are additional institutional factors that deserve attention in the analysis of cases like Korematsu. Whether and to what extent the outcome in Korematsu was a product of ignorance about the depth and importance of racism or the product of fear of confrontation is not an easy question. Some of the Justices seemed willing to confront the political process in Korematsu itself, and there can be little doubt about Justice Murphy's sensitivity to racism and political bias. In the same Term, the entire Court risked confrontation with a wartime government when it unanimously invalidated the authority of the War Location Commission to intern those excluded from the west coast without an actual showing of individual guilt. ${ }^{82}$ But no matter how one explains the result in the particular case, these concerns about institutional capacity are important questions, pointing up the need for a careful and systematic institutional comparison.

\section{F. The Pentagon Papers Case}

New York Times v. United States ${ }^{83}$ is a more recent example of a case in which an area of traditional suspicion of the political branches (prior restraints on the publication of political information) combines with an area of difficulty for the judiciary (national security and foreign intelligence). The executive branch sought an

\footnotetext{
- See the discussion of institutional capital supra note 32.

:2 Ex parte Endo, 323 U.S. 283 (1944). Justice Roberts concurred in the result.

as 403 U.S. 713 (1971).
} 
injunction against publication of reports prepared for the government on the conduct of the United States's war effort in Southeast Asia. The information was arguably both sensitive for reasons of national security and politically embarrassing.

Prior restraint on publication is generally perceived as perhaps the most egregious example of an impermissible governmental abridgement of the freedom of speech and of the press. ${ }^{84}$ Political incumbents have both the motive and the ability to keep information embarrassing to them away from the general public. Given this traditional source of distrust, the government confronted a difficult task in its effort to enjoin publication. As the short per curiam opinion noted, "[a]ny system of prior restraints of expression comes to this court bearing a heavy presumption against its constitutional validity."8s

In fact, the government was unable to overcome this presumption, but it came close. There were three dissenters and, of the six Justices who rejected the government's plea, three took positions suggesting that the result would have been different had the injunction been sought on the basis of a violation of an act of Congress or even of the violation of a prior Executive Order. ${ }^{86}$ It appears, thus, that the government might well have been able to impose a prior restraint on publication if the proper political institution had made the decision-a formulation quite analogous to the "structural due process"87 approach taken in Hampton. As in Hampton, too, there was a recognition of the problems confronting the judiciary: "[I]t is elementary that the successful conduct of international diplomacy and the maintenance of an effective national defense require both confidentiality and secrecy." Court was faced with a case implicating foreign affairs and foreign intelligence. Specifically, the Court had the task of assessing the

ss There is some evidence that the framers of the first amendment may have meant to cover no more than prohibitions on prior restraints. See Z. ChafeE, FreE SpeEch IN THE United States 9-12 (1941); L. Levy, Legacy of Suppression: Freedom of Speech and Press in Early American History 200-01 (1960); Chafee, Freedom of Speech in War Time, 32 Harv. L. Rev. 932, 938-39 (1919); Emerson, The Doctrine of Prior Restraint, 20 LAW \& Contemp. Probs. 648, 650-52 (1955).

ss 403 U.S. at 714 (quoting Bantam Books, Inc. v. Sullivan 372 U.S. 58, 70 (1963)).

ss Justices Marshall and White stressed the absence of congressional action outlawing such publication. 403 U.S. at 747 (Marshall, J., concurring), 732 (White, J., concurring). Justices Stewart and White stressed the absence of either a congressional act or clearly promulgated executive regulations. Id. at 728-30 (Stewart, J., concurring, White, J., joining).

${ }^{87}$ Tribe, Structural Due Process, 10 HARv. C.R.-C.L. L. REv. 269 (1976) (coining phrase "structural due process").

${ }^{88}$ New York Times v. United States, 403 U.S. at 738 (Stewart, J., concurring). 
impact of the release of sensitive information on these subjects.

The opinions of the other three Justices who found the restraints invalid also show the difficulty in assessing the implications of releasing this information. Justices Black, Douglas, and - Brennan took an absolutist position: under virtually no circumstances should an injunction be issued to restrain publication. ${ }^{\mathbf{9}}$ Such a position is consistent with Scharpf's observation that the Court's lack of access to information often produces sweeping or "absolute" solutions.90 These Justices recognized that a more discriminating approach to prior restraint is generally unrealistic. The Court may speak of scrutinizing the materials and claims of the government, but its actual ability to assess such materials and claims independently is usually extraordinarily limited.

The majority and dissenters alike struggled with the same institutional quandary. Cases construing the first amendment treat prior restraints on speech as a most suspect-if not an absolutely precluded-governmental restriction of speech and press. ${ }^{91}$ Nonetheless, as the dissenters argued, thereby articulating an approach that expressly paralleled the political question doctrine, the restriction allegedly served an important governmental purpose that is not easily amenable to independent assessment by the judiciary. ${ }^{92}$ In the final analysis, all of the opinions in the case reflect the importance of institutional choice, and it is again difficult to see how the case can be understood without understanding the institutional perceptions of the Justices or evaluated without a careful consideration of the relative institutional capacities of the courts and the political branches.

\section{G. Hard Cases and Beyond}

From the political question doctrine and Scharpf's analysis of it, I have moved to a consideration of cases in which questions of foreign affairs, war, and national security-issues which severely strain judicial competence-arise in conjunction with parallel strains on the credibility of the political process. The outcomes of the cases, the levels of scrutiny employed, and the range of ap-

89 Id. at 719 (Black, J., concurring), 720 (Douglas, J., concurring), 725 (Brennan, J., concurring).

- See supra notes 38-39 and accompanying text.

"See, e.g., Near v. Minnesota ex rel. Olson, 283 U.S. 697 (1931).

12403 U.S. at 757-58 (Harlan, J., dissenting). Justice Blackmun expressly joined this dissent. Id. at 759 (Blackmun, J., dissenting). Chief Justice Burger, while expressing general agreement with Justice Harlan's opinion, argued that the case was not properly before the Court for decision. Id. at 752 (Burger, C.J., dissenting). 
proaches taken by the various Justices reflect the interaction of these conflicting institutional forces.

These are hard cases in institutional terms. The decisions are controversial, their reasoning strained, and their doctrinal theories sometimes novel. It is commonly claimed that hard cases make bad law. But when hard cases force the Court to confront obvious strains and difficulties, they show us the underlying structure of decision in its starkest terms. Judges deciding such cases are forced to search a little deeper to decide and to explain their decisions, and the controversies among judges engendered in the course of such decisions reveal otherwise hidden assumptions and reasoning.

In these cases, the content of individual rights appears to be dependent, at least in part, on institutional factors. When the Korematsu majority stated that racial classifications were suspect and that government action employing them would be rigorously scrutinized, it provided a practical civil right based on a classic source of distrust of the political process, racial prejudice. Lawyers whose clients are harmed by such classifications have something to work with; they have a reasonable chance of successfully defeating such governmental action. But the case also showed that where these grounds for suspicion of the political process are combined with subject matter which strains the competence of the judiciary, the potential for success and for vindication of the associated civil right are both put in doubt. Korematsu provided a practical right against government mistreatment based on race, but it was conditioned on the ability of the Court to handle the issue in the particular context in which it was presented. New York Times defined and upheld a traditional right to be free of prior restraint, but it also signaled potential limits on that right reflecting the Court's inability to handle certain related substantive issues and its deference to the superior abilities of other branches. The "novel conception"9s in Hampton explicitly recognized conflicting institutional concerns, and defined a right that attempted to accommodate them.

Beyond the realm of foreign affairs, war, and national security, there are good grounds to believe that institutional forces are still at work. The problems of access to information and ability to understand and control larger contexts are pervasive. Important issues tend to be complex issues. The funding and administration of

93 Hampton v. Mow Sun Wong, 426 U.S. 88, 117 (1976) (Rehnquist, J., dissenting). 
major public undertakings-education, health, and criminal justice-present problems analogous to those faced by the judiciary in the cases we have discussed. These are vast enterprises, usually operated by administrative agencies controlled by the legislative and executive branches. Courts have limited; albeit varying, expertise in these areas. Furthermore, the typical case will usually present a court with a poor opportunity to exercise the expertise it has, since any controversy is likely to involve only a small part of the larger enterprise. Yet, as with the hard cases I have discussed, the legislative decisions underlying such controversies can impose burdens on discrete and insular minorities, restrict political speech and association, or otherwise give rise to serious suspicions of the political decisionmaking process.

The institutional tensions apparent in the hard cases, then, are present as well in many other constitutional cases, though the range of cases and the different institutional conditions and outcomes are too varied to be treated in detail here. It is enough to observe for present purposes that the Court's constitutional jurisprudence tolerates varying degrees of judicial intervention. With respect to the equal protection cases, Justice Marshall has argued that while the Court has tended to speak as though there are only two extreme levels of scrutiny-strict and minimal-it often operates as though there is in fact a spectrum of varying levels of scrutiny. ${ }^{94}$ Where along this spectrum a case falls depends, in Marshall's view, upon the suspiciousness of the classification in question and the fundamentality of the right or interest infringed..$^{25}$ The Court's responses in the reverse racial discrimina-

9 See San Antonio Indep. School Dist. v. Rodriguez, 411 U.S. 1, 98-100 (1973) (Marshall, J., dissenting); Dandridge v. Williams, 397 U.S. 471, 519-21 (1970) (Marshall, J., dissenting).

ss San Antonio Indep. School Dist. v. Rodriguez, 411 U.S. 1, 99 (1973) (Marshall, J., dissenting). The concept of fundamental rights and interests employed in both equal protection and substantive due process cases is cloaked in mystery. As the Court has itself pointed out, fundamentality in a constitutional sense is not determined by the societal significance of the interest involved. See id. at 30 . Instead, the question is whether the right is explicitly or implicitly guaranteed by the Constitution. But the process of implication appears selective enough to suggest that the basic question is being begged. It is noteworthy that many of the fundamental rights have been derived by implication from the first amendment and involve political activity, the integrity of which is a powerful institutional concern. Solicitude for such rights may well reflect the basic distrust of legislation enacted by incumbents that directly promotes incumbency. Other fundamental rights identified by the Court-principally privacy rights-remain largely unexplained and difficult to distinguish from other important societal interests given far less attention by the Court. Since issues of unconventional sexual choice may involve a configuration of interests in which members of a restricted minority each suffer a substantial harm while members of the majority benefitted 
tion and gender discrimination cases seem to support Marshall's argument. ${ }^{96}$ Moreover, in the cases in which Marshall, writing in dissent, articulated his sliding scale or spectrum analysis, the Court majority may well have been using, albeit not articulating, a sliding scale of its own. In both cases, the majority declined to intervene because the classification in question was not clearly suspect and because the judiciary was not competent to deal with the substantive issues involved. ${ }^{97}$ Recalling that suspiciousness is a measure of the likelihood of legislative malfunction, ${ }^{98}$ it seems at least plausible to hypothesize that in these cases the Court was basing its decision as to whether it would intervene in part on an assessment both of its ability to deal with the social issues involved and on the level of distrust engendered by the underlying action of the political branches. The Court's assessment of the presence of these concerns in each case, this analysis suggests, will determine, at least in part, its willingness to intervene and the degree of its intervention.

In this overview of the comparative institutional approach to constitutional law, I have offered working definitions of the basic institutions, as well as some conceptions of institutional defect or malfunction, all to show that even these simple notions can organize and facilitate the analysis of important constitutional cases. It may be disturbing to some readers that my analyses of the cases in this part of this article have focused on what judges have said. After all, judges may talk in terms of institutional analysis and decide on other grounds. ${ }^{99}$ But the central place given institutional

by the restriction each enjoy only a small gain, the political process, given a simple majority voting model, may be suspect as a decider of social good for such issues. For further discussion of this form of legislative malfunction, see Komesar, supra note 13, at 223-29.

The concept of fundamental rights and interests deserves lengthier treatment than it can receive here. As I suggest below, I believe that such a treatment will show that a definition of fundamental rights or interests itself is a proxy for a comparative institutional determination. See infra text following note 200.

See Regents of the Univ. of Cal. v. Bakke, 438 U.S. 265 (1978); Craig v. Boren, 429 U.S. 190 (1976).

${ }_{97}$ San Antonio Indep. School Dist. v. Rodriguez, 411 U.S. 1 (1973), was a case involving the constitutionality of using local property taxes to finance schools. Although the Rodriguez majority stated that practical considerations had no role to play in the adjudication of the constitutional issues presented, it plainly was concerned with the competence of the judiciary to decide the issues of educational policy and taxation involved. See id. at 56-59.

Dandridge v. Williams, 397 U.S. 471 (1970), involved the extent of a state's duty to fund welfare. Again, the majority made clear that it considered this issue to be a difficult one for the judiciary. See $i d$. at 487.

${ }_{98}$ See supra notes $11-17$ and accompanying text.

99 See Tribe, The Puzzling Persistence of Process-Based Constitutional Theories, 89 YALE L.J. 1063, 1063-65 (1980) (noting judges' attraction to writing as though they were 
comparison here did not stem from its articulation in judicial opinions. The causal relationship is the opposite. Institutional comparison is an essential element of constitutional law. It is not surprising, therefore, to see it in judicial opinions. Such articulations, however, are not essential to my argument. On a normative level, it makes no difference whether judges believe they are making institutional choices. The fact remains that they are making institutional choices, and an analysis of institutional choice is essential in evaluating their decisions. But, even on a descriptive level, proof that judges did not think in institutional terms would not alone belie my characterization of their actions. ${ }^{100}$

As I have noted, the judicial decisions examined here are particularly significant because they involved difficult and important institutional choices, and the deciding judges appeared to have appreciated this fact. Perhaps those judges employed institutional considerations cynically - an unestablished proposition in my view. But even if they did, the irony would be that what was employed as make-weight turned out to be, in essence, what should have been considered.

The remainder of the article examines some of the recent attempts at institutional analysis in the constitutional law literature as well as some recent expressions of skepticism about the relevance of institutional analysis. Although the constitutional scholars considered here offer some valuable institutional insights, they do not offer a comparative analysis of institutional attributes and, therefore, make basic analytical errors. In the end, they force narrow institutional analyses to yield broad conclusions about constitutional law. Both the contributions and the limitations of these analyses, however, are useful in my search for a fuller understanding of comparative institutional analysis.

I will be harder on the scholars than I have been on the judges. Because they are not faced with the responsibility and demands of making decisions, scholars have the luxury to speculate about their concerns and to recognize explicitly the tentative and experimental nature of their theories. As a consequence, they remain the best source of general theory, and critical examination of their efforts is justifiably the core of theory building. When, in future work, the general theory is turned on specific cases, there will

helping to perfect the political process only and were not making choices among substantive values).

${ }^{100}$ I have explored this theme in Komesar, supra note 1, at 1354-56, 1363-65. 
be time enough to examine the work of the Court with a more critical eye.

\section{The Role of Political Malfunction: The Approach of JoHN HaRT ELY}

In Democracy and Distrust, ${ }^{101}$ Dean John Hart Ely offers an institutionally-based conception of constitutional judicial review that focuses particularly on the attributes of the political process. To Ely, the political branches should determine social policy, and the judiciary-the least democratic branch-should be restricted to correcting malfunctions in the more democratic political branches. The judiciary's task is to assure that democratic institutions properly arrive at substantive decisions. ${ }^{102}$ The judiciary, in other words, perfects the political process; process-not substance-is the correct, the legitimate, and the intended business of the judiciary. ${ }^{103}$

Ely's theory has descriptive as well as normative aspects. $\mathrm{He}$ sees in the text of the Constitution and in its interpretation by the Supreme Court a basic concern with departures from the democratic political process. ${ }^{104}$ To Ely, this concern is epitomized in the famous Carolene Products footnote, which signalled the end of the interventionist era of "economic due process," but which also set out those circumstances in which judicial intervention might still be expected. ${ }^{105}$ To Ely, these circumstances are ones which raise concerns about malfunction in the political process and about.its correction.

Ely's approach constitutes a serious and significant attempt at an institutional analysis of constitutional law. He sees the Constitution as concerned primarily with the mode of decisionmaking rather than with dictating specific decisions. He carries forward this view of the central place of decisionmaking into an analysis of the role of the judiciary which begins, wisely in my view, by recognizing the Constitution's primary reliance on the political process. For Ely, the judiciary's role only begins when there are serious problems with the political process. ${ }^{106}$ His concern about the attributes of the political process is more than an afterthought. It is

101 J. Ely, supra note 15.

${ }^{102} I d$. at $73-75,77-88$.

${ }^{103}$ Id. at 181.

104 See id. at 73-77.

${ }^{105}$ United States v. Carolene Prods. Co., 304 U.S. 144, 152 n.4 (1938). The text of the footnote appears infra note 143.

${ }^{108}$ See, e.g., J. ELY, supra note 15, at 103. 
the central feature of his analysis.

But Ely's analysis, however important, is basically incomplete. He does not acknowledge that malfunction is a product of the imperfection endemic to all human institutions, including the judiciary. Whereas Ely explores the imperfections of the judiciary with great gusto in, for example, his criticism of the fundamental rights theorists, ${ }^{107}$ he virtually ignores these imperfections in developing his own theory. $\mathrm{He}$ is unable, therefore, to weigh effectively the defects in the judiciary against the defects in the political branches. He sees that the ability of the political process to function varies across the range of social issues-for example, those that involve race or speech versus those that do not. But he does not observe that the competence of the alternative institution-the judiciary-may be similarly variable. Accordingly, he does not compare the respective institutional imperfections across the range of constitutional issues. As I have demonstrated, social issues that raise the spectre of legislative or executive malfunction, such as. those involving race or speech, can also involve foreign affairs, war, and the administration of complex social programs-issues that raise questions of judicial incompetence. The presence of strains on the political process in such instances is relevant, but it is not determinative. In the end, although Ely provides a central place in his theory for institutional considerations, his analysis of those considerations fails to place them fully in context.

In place of a careful comparison of institutional attributes, Ely substitutes a distinction between process and substance: the judiciary's role is to police the political process and to correct political malfunction, while it is the role of the political process to make value determinations and value judgments. ${ }^{108}$ This simple distinction is not an adequate substitute for institutional comparison. As I shall demonstrate, the task of policing the political process in fact requires the judiciary to make difficult and important value judgments and to substitute these judgments for those made by the legislative process. In making these judgments, the judiciary is necessarily involved in precisely the tasks for which Ely supposes them ill-suited. ${ }^{109}$ Yet, at the same time, Ely suggests, the political process is also ill-suited to make these judgments. To avoid this impasse, an institutional analysis needs something more than Ely's process/substance distinction can provide.

107 See id. at 44-45, 56-60.

108 See id. at 181.

${ }^{109}$ See id. at 43-69. 
Beyond its failure to compare meaningfully the legislative and judicial processes, Ely's analysis is also built upon an overly narrow understanding of legislative malfunction. The problems he identifies are certainly important, but they are far from the only important sources of malfunction to be found in our governmental tradition. Ely's limited perception of legislative malfunction is probably related to his failure to consider the corresponding malfunctions of the judiciary. Since he relies so heavily on the attributes of the legislature to justify both the existence of and the limits on the judicial role, he appears forced to place artificial limits on his list of legislative defects.

I shall explore these features of Ely's analysis in two ways. First, I shall examine Ely's basic institutional arguments. I shall then turn to an examination of the Carolene Products footnote, the central judicial manifestation of Ely's theory.

\section{A. Ely's Institutional Theory}

The essence of Ely's theory and his institutional argument is captured in two paragraphs worth full quotation here:

The approach to constitutional adjudication recommended here is akin to what might be called an "antitrust" as opposed to a "regulatory" orientation to economic affairs-rather than dictate substantive results it intervenes only when the "market," in our case the political market, is systemically malfunctioning. (A referee analogy is also not far off: the referee is to intervene only when one team is gaining unfair advantage, not because the "wrong" team has scored.) Our government cannot fairly be said to be "malfunctioning" simply because it sometimes generates outcomes with which we disagree, however strongly (and claims that it is reaching results with which "the people" really disagree-or would "if they understood" - are likely to be little more than self-deluding projections). In a representative democracy value determinations are to be made by our elected representatives, and if in fact most of us disapprove we can vote them out of office. Malfunction occurs when the process is undeserving of trust, when (1) the ins are choking off the channels of political change to ensure that they will stay in and the outs will stay out, or (2) though no one is actually denied a voice or a vote, representatives beholden to an effective majority are systematically disadvantaging some minority out of simple hostility or a prejudiced refusal to recognize commonalities of interest, 
and thereby denying that minority the protection afforded other groups by a representative system.

Obviously our elected representatives are the last persons we should trust with identification of either of these situations. Appointed judges, however, are comparative outsiders in our governmental system, and need worry about continuance in office only very obliquely. This does not give them some special pipeline to the genuine values of the American people: In fact, it goes far to ensure that they won't have one. It does, however, put them in position objectively to assess claims-though no one could suppose the valuation won't be full of judgment calls-that either by clogging the channels of change or by acting as accessories to majority tyranny, our elected representatives in fact are not representing the interests of those whom the system presupposes they are..$^{110}$

A great deal is packed into this short passage. First, Ely posits an antitrust analogue for constitutional law, focusing upon malfunctions in the political process. Second, he offers a two-part definition of malfunction. Third, he asserts that the judiciary is the institution best adapted to addressing malfunctions in the political process-a role it appears to win by default. Each step has fundamental problems.

1. The Antitrust Analogy. According to Ely, antitrust law warrants judicial intervention only when there is a "systematic malfunction" in the market. Applying this principle to constitutional law, Ely would have the judiciary intervene only when there is a systemic malfunction in the political process-the "political market." Ely contrasts this antitrust approach, which confines intervention to correcting malfunctions in the market itself, with a "regulatory" approach, which allows the intervenor to "dictate substantive results." Presumably, to complete the analogy, the fundamental rights theories that Ely so strongly criticizes ${ }^{111}$ would be the constitutional counterpart to this regulatory approach in that they would have the courts dictate substantive results.

The analogy seems apt, but because there is an analytic flaw in Ely's description of the antitrust and regulatory modes of intervention into economic affairs, the analogy does not yield the point Ely seeks to establish. In fact, the analogy undercuts the strength of Ely's process/substance distinction as a means of allocating institu- 
tional responsibility. The difference between the two approaches to economic affairs is not that one is triggered by "systemic malfunction" while the other is not. Both are most accurately viewed as reactions to malfunctions of the market. They differ in the form of intervention, not the reason for intervention.

The antitrust approach is a corrective form of intervention. Antitrust actions are aimed at correcting the market malfunction by removing an impediment to the proper functioning of the market. Where collusion by producers or sellers sets a price higher than the competitive price and a quantity lower than the competitive quantity, the antitrust response is to remove the collusion, so as to allow market forces to set price and quantity. The regulatory approach, in contrast, is a substitutive form of intervention. Rather than attempting to remove the impediment to the market as a decisionmaker, an agency of government regulates or sets prices, or quantities, itself. The choice between these modes of intervention depends on a comparison of institutional attributes in a given setting. Collusion, for example, may be more conducive to correction (antitrust), while natural monopoly may call for substitution (regulation). The range of potential market malfunctions is large-problems of information and organization, third party effects, as well as monopolies-and there is a corresponding array of techniques for intervening in response to these malfunctions. The correct choice will depend on the particulars of the malfunction to be addressed as well as on the attributes of the means available to address it.

Ely's analogy, then, entails institutional complexities that he does not consider. In the world of economic affairs there is always some "malfunction" in Ely's sense, always some deviation from ideal conditions. Systemic malfunction itself is therefore never a sufficient condition to determine either whether or how to intervene. Rather, the questions of whether and how to intervene depend on the relative strengths and weaknesses of the alternative modes of intervention. Like the market itself, the institutions that enforce the antitrust laws and impose regulation are imperfect-they require resources for their administration and they can make costly mistakes. When, and in what form, intervention is useful in economic affairs is a basic, difficult, and controversial comparative institutional question. There is no preferred solution for all settings.

What is true for the economic analogy is also true for constitutional law. Whether the judiciary is to play any role, and what that role should be, should not be determined simply on the basis of the 
existence or nonexistence of malfunction in the political process. Ely may be right to criticize fundamental rights theorists for calling too cavalierly for the substitution of the judicial value judgments for those of the political branches. As I shall argue subsequently, those analysts do overlook key comparative institutional questions. But it does not follow that substitution need always be associated with insensitivity to institutional factors, or that substitution is always institutionally inferior to correction or any other mode of intervention (including nonintervention).

2. The Role of the Judiciary. These observations raise the basic question: Why should "correction," or process, be the business of the judiciary and "substitution," or substance, be the business of the legislature? Ely addresses the first part of this question directly only in the passage we have been examining and then only in one sentence: "Obviously our elected representatives are the last persons we should trust with identification of [legislative malfunctions]." 112 To Ely, this assertion points to judges as guardians of the political process because they are "comparative outsiders to the governmental system." tempts to explain why correction or process is the business of the judiciary and, therefore, the basis of constitutional judicial review, form far too weak a foundation to support the analytical structure he builds. Ely's assertion that the political process and its central actors should not be entrusted with the task of identifying and correcting legislative malfunctions manifests a simple principle-that one cannot reliably judge or correct oneself. This principle, correctly qualified and employed, certainly has relevance to the allocation of institutional responsibility, but it is not alone a sufficient basis for disqualification. It identifies only a potential imperfection in one of the alternative institutions. It is probably correct to say that an institution attempting self-correction should necessarily be open to some degree of distrust, but, given the inevitable existence of imperfections in any alternative institutions, recognition of a single problem in the political branches is an insufficient basis for allocating decisionmaking responsibility to other institutions.

Consider, for example, Ely's first form of political malfunction. Is it obvious that attempts to "choke off the channels of political change" in order to retain power for the "ins" would not or could not be deterred or controlled in the absence of judicial intervention? Were there no longer judicial review, there would not neces- 
sarily be a rapid transformation of the government into a dictatorship or oligarchy. Voters, perhaps spurred on by those who themselves wished office, could be expected to penalize those officials who attempted to curtail seriously valued rights of free speech and free press. Sweeping attempts to alter the makeup of the electorate or reallocate votes geographically might also be penalized in a political process in which power is shared among branches and levels of government. Our political process has a great many "ins" with a great diversity of desires. This diversity of individuals and desires, in combination, makes it difficult for a stable majority capable of choking off change to coalesce on a broad range of issues. Thus, despite a long period of judicial inactivity on process, voting, and speech, it was nevertheless the case that politically corrupt legislatures produced reforms, the franchise was extended, and the press functioned in an effective manner. ${ }^{114}$

Nor have the political branches shown themselves completely unable to combat legislative prejudices and stereotypes-the second type of malfunction that Ely identifies. Remedies for gender discrimination have come as often from the political process as from the judiciary. It was the political process, for example, that eventually provided suffrage for women through the nineteenth amendment. ${ }^{115}$ Similarly, both after the Civil War and during the past two decades, Congress intervened to curtail discrimination against blacks that affected state political processes. ${ }^{116}$

114 One could, of course, contemplate a massive totalitarian suppression of speech, assembly, and the franchise. Under those conditions, it would be difficult for the internal functions of the political process to correct the suppressions. Bayonets and tanks could silence effective political dissension. But faced with such an extreme failure of democratic institutions, the debate about the proper scope for judicial intervention would become moot, since the judiciary would be powerless; the power of the judiciary depends on a functional political process, see supra text following note 80 .

118 U.S. Const. amend. XIX. For a list of other legislation enacted to correct gender discrimination, see infra note 195.

${ }_{116}$ See, e.g., Civil Rights Act of 1968, Pub. L. No. 90-284, 82 Stat. 73 (codified in scattered sections of 18 U.S.C., 25 U.S.C., 28 U.S.C. and 42 U.S.C. (1982)); Voting Rights Act of 1965, Pub. L. No. 89-110, 79 Stat. 437 (codified at 42 U.S.C. $\$ \$ 1971$, 1973-1973bb-1 (1982)); Civil Rights Act of 1964, Pub. L. No. 88-352, 78 Stat. 241 (codified as amended at 28 U.S.C. $\S 1447,42$ U.S.C. $\S \S 1971,1975 \mathrm{a}-\mathrm{d}, 2000 \mathrm{a} \&$ note $2000 \mathrm{~h}-6$ (1982)); Civil Rights Act of 1960, Pub. L. No. 86-449, 74 Stat. 86 (codified as amended at 18 U.S.C. prec. $\$ 831$, $\S 1071,1074$, 1501, 1504; 19 U.S.C. § 1971 \& note; 20 U.S.C. § 241, 260; 42 U.S.C. $\S \S 1974-1974$ e, 1975d (1982)); Civil Rights Act of 1957, Pub. L. No. 85-315, 71 Stat. 634 (codified as amended at 5 U.S.C. § 294-1; 28 U.S.C. $\$ \S 1343$, 1861; 42 U.S.C. \$§ 1971, 1975 \& note 1975e, 1995); Civil Rights Act of 1875 , ch. 114, $\S 3-5,18$ Stat. 336,337 (current version codified at 18 U.S.C. § 243; 42 U.S.C. § 1984 (1982)); Civil Rights Act of 1871 (Ku Klux Klan Act), ch. 22, 17 Stat. 13 (current version codified at 42 U.S.C. $\$ \S 1983,1986$ (1982)); Civil Rights Act of 1870 , ch. 114, 16 Stat. 140 (current version codified at 42 U.S.C. $\$ \S 1971,1981,1987,1989$ - 
I do not mean to argue that political attempts to correct the problems in the political process have been sufficient, or overwhelmingly attractive, or that they have left no significant role for judicial intervention. I do contend that the political process is not self-evidently or inevitably the least desirable choice for correcting these problems-not when the choice is among imperfect alternatives. Since some correction can and does occur within the political process, one cannot declare a priori that the judiciary is better qualified to identify and correct a given political malfunction or political malfunctions in general.

There seems to be a basic contradiction in Ely's perception of judicial infirmities. Early in his book, Ely denounces those who would have the judiciary make basic social value judgments and details the inadequacies of the judiciary in making such judgments. ${ }^{117} \mathrm{He}$ depicts a judiciary severely limited in its ability to plumb the desires and needs of the populace-a judiciary clearly inferior to the political process in its ability to determine social policy. Given Ely's convincing demonstration of the limitations on judicial capacity, it is hard to understand why the judiciary should then be assigned the significant task that Ely assigns it simply by default. Institutional choice by default is generally suspect and seems plausible only when one institution is so clearly incapable of performing a given task that it is inconceivable that it could perform at any acceptable level, or when the alternative institution is overwhelmingly attractive and superior. Neither polar case seems to be present here.

The problem with Ely's analysis and the source of the tension in his theory should be evident. Ely has done institutional analysis on only one institution at a time. First, he argues at length that, given its inadequacies, the judiciary must be disqualified from deciding a range of social issues. Later, and without references to his critique of the judiciary, he concludes that the political process should also be disqualified from deciding a range of issues by reason of its malfunctions. Each institution is disqualified from a realm of activity by its imperfections without regard to the limitations of the other institution in that same realm.

3. Substance and Process. In addition to the two-paragraph institutional analysis I have just examined, Ely also argues that an institutional allocation based on the substance/process distinction

1991 (1982)); Civil Rights Act of 1866, ch. 31, 14 Stat. 27 (current version codified at 42 U.S.C. $\$ \$ 1982,1986-1987,1989-1992$ (1982)).

117 See J. Ely, supra note 15, at 43-72. 
he advocates is reflected in the Constitution itself. ${ }^{118}$ Ely is basically correct, in my judgment, when he argues that the Constitution is, by its nature, predominantly concerned with the processes of decisionmaking and the allocation of institutional responsibility for the various tasks that make up that process. But does the nature of the Constitution support Ely's particular institutional allocation? Does the Constitution exclusively or even predominantly allocate the task of policing the democratic process to the judiciary while denying that institution any significant role in the determination of substance? I believe that an examination of the Constitution reveals a far richer range of institutional choice.

Ely sees the Constitution as "devoted almost entirely to structure,"119 by which he means provisions "explaining who among the various actors-federal government, state government; Congress, executive, judiciary-has authority to do what, and going on to fill in a good bit of detail about how these persons are to be selected and to conduct their business." ${ }^{120}$ Ely's argument that much of the Constitution is devoted to a definition of the rules of the game and, therefore, to process seems cogent. ${ }^{121}$ But what does the Constitution tell us about the allocation of institutional responsibility in general and the role of judicial review in particular? Does it allocate exclusively or predominantly to the Court the business of giving content to these "structural" provisions and never allocate that task to the political branches? An affirmative answer to these questions does not follow from a reading of the document itself.

Many of the structural provisions of the Constitution are quite specific. Congress may not decide, for example, that the terms of its members shall be extended to ten years. But neither may the Court decide that the terms of the members of Congress shall be one year. Subject only to constitutional amendment, the framers made an institutional choice designed to exclude any future decisionmaker-be it Congress, the executive, the states, or the judiciary-from making such a decision. While, as a general matter, such exclusion sacrifices flexibility of decision because it does not allow for variation over time, one can nevertheless imagine reasons for so proceeding. The framers might well have envisioned that the fac-

118 See id. at 88-101.

110 Id. at 90.

$220 \mathrm{Id}$.

121 Others have argued that even these "structural" provisions were intended to promote substance. See Tribe, supra note 99, at 1065-67. Tribe's position is discussed infra text accompanying notes 187-201. 
tors bearing on a congressman's term of office were unlikely to change, or they may have harbored grave doubts as to the trustworthiness of any of the available future decisionmakers. Indeed, both of these reasons apply to such specific "structural clauses" as those setting the minimum ages for holding the various political offices and the terms of each office. Such matters could be arbitrarily specified without fear of significant future disadvantage. Moreover, as Ely so often points out, without such inflexibility actors within the political process might manipulate the provisions to retain office. The framers' actual institutional choice denied all future institutions the power to alter those provisions.

In the case of other structural provisions, the framers chose to allocate decisionmaking about process to the political branches themselves. For example, each house of Congress judges the qualifications of its members and sets it own rules of procedure. ${ }^{122}$ Vast hierarchies of questionable merit, such as the congressional committee system, ${ }^{123}$ have been built on this power. Similarly, the procedure for removing elected officials from office during their terms in office by impeachment and trial is also left to the houses of Congress. ${ }^{224}$

On a more general level, the system of checks and balances manifested in the separate political branches of the national government and the division of responsibility between national government and state government is a system of controls in which one political entity is intended to control another. Thus, for example, the commerce clause has been employed to curb, and has been seen to reflect, fears about the parochial biases of the states as decisionmakers. ${ }^{125}$ Ely persuasively justifies the judiciary's dormant commerce clause decisions as an effort to protect "voteless," out-of-state interests from such biases. ${ }^{126}$ The commerce clause in

122 U.S. Const. art. I, \& 5. This provision, of course, does not mean that there are no limits on these powers or that the Court never plays a role. See, e.g., Powell v. McCormack, 395 U.S. 486, 547-48 (1969) (denying congressional authority to exclude a member of the Congress except upon grounds set out explicitly in the Constitution). As a general matter, however, congressional qualifications and internal rules of procedure lie within the exclusive control of the political branches.

223 For a detailed description of this system as well as a good compilation of materials pertaining to it, see J. CHOPBR, supra note 4 , at 17-21, 38-42.

124 U.S. CoNST. art. II, $\$ \S 2-3$.

${ }^{128}$ See, e.g., Pike v. Bruce Church, Inc., 397 U.S. 137 (1970); Baldwin v. G.A.F. Seelig, Inc., 294 U.S. 511 (1935).

${ }^{198}$ See J. Ely, supra note 15, at 83. Ely makes a similar argument about the privileges and immunities clause of article IV. Id. He argues that state political processes by their nature, exclude the out-of-state interests from representation. Therefore, the Court can act under the commerce and privileges and immunities clauses to enforce "virtual representa- 
general, however, treats Congress, as well as the courts, as a correcting institution. The power of Congress to regulate interstate commerce was and is a basic institutional response to institutional problems with state regulation. Thus, the voteless "out-of-staters" are to be aided by two institutions, only one of which is outside the political process.

While the Constitution reveals the framers' concern with institutional choice, it does not reflect an intention to remove all decisions designed to perfect the political process from the political branches or allocate all or most of such decisions to the judiciary. Some are simply fixed and beyond the control of any future decisionmaker, including the judiciary. Others are assigned to political institutions, not to the judiciary. Although the Constitution is concerned with the policing of governmental processes, it does not make the judiciary the sole or even the dominant institution to carry out this function.

If decisions about process are not exclusively allocated to the judiciary, what is to be said of the other feature of Ely's theory-his view that the political branches should decide all questions of substance? ${ }^{\mathbf{1 2 7}}$ Ely concedes that a few constitutional provisions take substantive decisions away from the political branches, ${ }^{128}$ though these, he believes, are rare exceptions. Ely's critics have argued that his class of exceptions should be expanded to include a number of additional provisions, ${ }^{129}$ but the issues which most dramatically reveal the assignment of difficult and important value judgments to the judiciary are the ones Ely himself thinks safely within the process camp-equal protection and first amendment protection of speech and press. ${ }^{130}$

Ely's view of the first amendment is simply stated: the first amendment deals with speech-political speech predominantly-and with the press. These freedoms are basic to informed political choice and, therefore, to the functioning of the political process. Ely's notion that the first amendment concerns political

tion" of out-of-state interests as to state legislation that affects them. No one would claim that citizens of state $A$ should be entitled to vote in state $B$, but to the extent that the legislative acts of state $B$ affect the citizens of state $A$, there is a legislative malfunction that the Court might correct.

127 See id. at 92-101.

${ }^{128}$ Id. at $90-92$.

${ }^{128}$ See, e.g., Lynch, Book Review, 80 CoLum. L. REv. 857, 860-61 (1980) (classifying the third, fourth and eighth amendments as primarily substantive, and the fifth and sixth as a mix of substantive and procedural).

${ }^{130}$ See J. ELY, supra note 15, at 93-94, 98. 
information and is linked to the political process certainly follows a long tradition of constitutional interpretation. ${ }^{131}$ Many speech cases involve political speech, and many involve concerns about the throttling of that speech by politicians adverse to the message.

Other commentators have broader conceptions of the meaning of the first amendment, ${ }^{132}$ but even if one accepts Ely's narrower view, there is still no escaping the fact that speech cases can require the judiciary to make difficult substantive decisions. First amendment cases, after all, are not just speech or press cases; they are also cases about national security, the raising of armies, violence in the streets, the orderly use of public thoroughfares, the functioning of the judicial system, the privacy and morals of the populace, and the education of the young. ${ }^{133}$ In other words, they implicate subjects normally assigned to the political branches. If Ely were asked where these subjects belong in his constitutional order and were not told that speech issues were also present, he would surely respond that these are substantive matters involving determinations of basic value judgments and should therefore be assigned to the political branches. Nonetheless, in Ely's view, the presence of a first amendment concern removes determinations about these substantive matters from the political process and allocates them to the judiciary. If the judiciary is to protect speech and thereby the integrity of the political process, it must often make judgments about these underlying substantive issues. One might, of course, take the absolutist position that the first amendment merely calls on the Court to see if speech is restricted and, if it is, to strike down the legislation. But such a position is not consistent with Ely's interpretation of the first amendment, or with the interpretation given the amendment by a majority of the Court. ${ }^{134}$ As a consequence, the judiciary must consider the import,

${ }^{231}$ See T. EMERSON, The SySTEM of Freedom of Expression 7 (1970); A. MEIKLEJohn, Free Speech and Its Relation to Selp-Government 22-27 (1948); A. Meiklejonn, Political Freedom, the Constitutional Powers of the People 107-24 (1960); Bork, Neutral Principles and Some First Amendment Problems, 47 IND. L.J. 1, 20-35 (1971); Kalven, The New York Times Case: A Note on "The Central Meaning of the First Amendment," 1964 Sup. Cr. Rev. 191, 204-10; Karst, Equality as a Central Principle in the First Amendment, 43 U. ChI. L. REv. 20, 23-25 (1975).

${ }^{132}$ Some would argue that a further purpose of the first amendment is the protection of "personhood" or the dignity of individual thought. See, e.g., T. EmERSon, supra note 131, at 6; L. TRIBE, supra note 33, at 905-10; Karst, supra note 131, at 25-26.

${ }^{233}$ See cases cited infra notes 135-36.

134 Even if the Court were to take such an absolutist position, it would nevertheless be true that substantive decisionmaking would be removed from the political process-decisionmaking, moreover, involving subjects beyond speech and press. Thus, the institutional choice implicit in even the absolutist position takes from the political branches 
weight, and validity of substantive values or interests. The Court is called upon to review decisions that balance speech interests with such interests as protection against violence in the streets, ${ }^{135}$ the orderly functioning of schoolrooms, ${ }^{136}$ and national security. ${ }^{137}$ It must deal with substance in order to guard the process.

It is important for two reasons to understand that first amendment cases encompass both questions of process and substance, as Ely uses those terms. First, the observation suggests that it is the nature of the Constitution to assign certain difficult substantive tasks to the judiciary, albeit in part because of defects in the political process. Second, if these are difficult substantive issues, and if Ely is correct when he argues that the judiciary is far from perfect or even severely defective as a substantive decisionmaker, then it is no longer sufficient to argue that the Constitution ought to assign these tasks to the judiciary simply on the basis of defects in the political process. By Ely's own arguments, both institutions are severely defective. Therefore, assignment of the task on the $a$ priori basis of political malfunction is insufficient. Either as description or prescription, Ely's analysis of institutional decisionmaking responsibility remains incomplete.

A look at Ely's other core subject-the representation of minorities and its grounding in the equal protection clause-yields similar conclusions. According to Ely, the equal protection clause is meant to correct a problem with the legislative process: classifications based on prejudice, whether deriving from open hostility or from self-serving stereotypes. Either because they are members of the majority or because they serve the wishes of the majority, political representatives often fail to represent those groups against whom this prejudice is directed. Despite this element of failure of process, equal protection cases, like first amendment cases, require the judiciary to make important and difficult substantive determinations. Equal protection cases can and do involve a broad range of social issues. Prejudice, after all, may lie behind any form of legislation. Categorization, classification, and differentiation are the core of social policymaking. If policy is to be made, the political branches must differentiate among groups. The identification of a serious prejudice that influences the political process only tells

substantive authority that Ely sees as generally belonging to them. See supra notes 83-88 and accompanying text (discussing New York Times v. United States, 403 U.S. 713 (1971)).

${ }^{138}$ See Terminiello v. Chicago, 337 U.S. 1 (1949).

${ }^{136}$ See West Va. State Bd. of Educ. v. Barnette, 319 U.S. 624 (1943).

${ }^{137}$ See New York Times v. United States, 403 U.S. 713 (1971) (per curiam). 
us that there is a tendency to underrepresent certain interests. But it is entirely possible that the same decision might have been produced by an unbiased process ${ }^{138}$ - a process, in Ely's terms, untainted by hostility or self-serving stereotypes. Who, then, is to decide whether a classification emanating from the defective political process is to stand? If, as Ely believes, a showing of prejudice should shift the burden to the government to demonstrate that the same policy decision would have resulted even if no such motive had existed, the judiciary is left with the obligation of making the basic classification decision.

The government can usually rationalize the outcome in unbiased terms, if only because most controversial and important policy decisions involve legitimate concerns on each side; in Hampton, for example, the government raised concerns about foreign affairs and foreign policy. ${ }^{139}$ Once the government has raised a colorable nonprejudicial explanation, the courts must then determine whether the considerations presented by the government outweigh the detrimental effects of the legislation. That determination is a substantive one, much like the determination the legislature was supposed to have made. In the extreme, if the courts cannot easily assess the validity of these arguments, they are then faced with the Scharpf dilemma discussed earlier: ${ }^{140}$ either they must accede to the government's arguments and thereby diminish the protection of minorities, or they must dismiss the government's arguments and thereby risk the invalidation of worthwhile legislation. In such cases, the courts are faced with difficult substantive decisions. In allocating the decisionmaking responsibility, the ability of the judiciary to make the substantive decision in question must be weighed against the demonstrated disability of the political branches.

Ely is correct, in my view, when he asserts that the Constitution basically serves to allocate decisionmaking responsibility rather than to impose specific substantive results. He also is correct when he argues that problems with the political process are and should be important in determining that allocation. But neither the nature of the Constitution nor Ely's institutional analy-

138 This realization comes through in the Court's cryptic footnote 21 in Village of Arlington Heights v. Metropolitan Hous. Dev. Corp., 429 U.S. 252, 270 n.21 (1977), where the Court noted that proof that the village was motivated by prejudice does not automatically require invalidation of its actions if the same action would have resulted absent prejudicial purpose.

139 See supra text accompanying note 55 .

${ }^{140}$ See supra text accompanying notes 38-39. 
sis indicates that the judiciary is or should be given all and only tasks of policing the political process. Whether the judiciary is better or worse than the political branches at these tasks is not necessarily decided by the fact that the political branches are imperfect or even highly imperfect. The political branches, clearly, will never correct themselves in an ideal or perfect manner (however that ideal is defined), but the important question, as I have stressed repeatedly, is whether they will do a better or worse job of correction-that is, of deciding substantive decisions associated with speech or classification issues-than will the also highly defective judiciary.

Neither is it obvious that the judicial response should be limited to correction of the political process. Suppose, after all the corrective efforts of the judiciary, political process defects still remain-as they surely will. Is it obvious that the judiciary should never respond to legislation emanating from the still defective political process by substituting its own, admittedly imperfect judgment? Perhaps, as Ely's analysis would suggest, it is true that the Court should confine itself to processes-implicating issues such as voting or speech while steering clear of a substantive issue such as abortion. But if Ely is correct, his conclusion does not follow solely from his institutional analysis. More careful consideration of the relative abilities of the institutions in question than has so far been undertaken is necessary before the question posed above can be answered.

There is one further problem with Ely's institutional argument. To Ely, "malfunctions" in the political branches are the basis for judicial intervention. While, in my view, such malfunction alone is not a sufficient condition to determine when and how to intervene, it is an important feature of a comparative institutional analysis. Malfunction in the political branches, however, is not necessarily limited to the two forms Ely identifies, namely, attempts by those in power to choke off the channels of political change and the systematic disadvantaging of some minority out of simple hostility or prejudice. Since we are concerned here with laying the groundwork for future institutional analysis, it is important to see that however important the political malfunctions Ely identifies may be, they do not constitute a closed set. ${ }^{141}$ In an effort to

142 Even Ely's definitions of his two forms of political malfunction reveal analytical problems that will require careful consideration in future efforts at institutional analysis. Consider Ely's view that the protection of speech stems from the first form of malfunction, distrust of the desire of "ins" to stay in. See J. Ely, supra note 15, at 103. This desire does 


\section{illustrate this point and to explore further the limits of Ely's insti-}

not identify malfunction in the political process as such. That "ins" wish to stay in is a normal feature of politics-not necessarily a malfunction. This desire to retain elective office is what makes officials responsive to the electorate.

Elected representatives may want to suppress free speech for their own selfish interests, but they also may want to take money from the treasury or regulate commerce or lay taxes for their own selfish interests. That they would want to do so does not mean that they can. Ely would argue that misappropriation of funds or favoritism in legislation would in general be deterred by the fear of losing office. But wouldn't the same fear curb invasion of free speech? Isn't favoritism in the granting of a license to a butcher the same as favoritism in the granting of a license to print and publish? All this potential selfish misbehavior is serious. Why is one type a form of malfunction for which we need judicial intervention, whereas another is not?

It is true that suppression of speech or press deprives the public of something that is valuable to them as participants in the political process. Income or jobs may not so directly implicate political activity. But if the public would rise up and vote out anyone who curtailed its access to information, the self-interested elected representative would not dare attempt to do so. This point must be qualified, of course, by the recognition that if access to information is curtailed, voters may not know enough to protect themselves at the polls.

Ely needs more than a reference to the selfish desires of the "ins." It is likely that the subjects of speech and the press-important as they are to the functioning of the process of making public policy-are poorly handled by the political branches because concern for them is unequally distributed among the population. It may be that the majority of the population does not well appreciate the value of speech or press; if speech is highly valued only by a few, then the "ins" can take their selfish advantage by curtailing speech with little fear of reprisal at the ballot box.

Ely's second form of malfunction-hostile or prejudicial refusal to recognize and represent the interests of minorities, see id.-comes closer to recognizing that something more than a theory of selfish motives is needed to explain the shortcomings of the political process. Here the malfunction is tied more closely to the majoritarian nature of politics. If an elected representative were hostile toward, or held self-serving stereotypes about, a politically powerful group, we would expect any resulting misbehavior to be well controlled by the electoral process. The existence of hostility or stereotypes is not the dominant problem; a significant risk that misbehavior would go uncorrected by the political process must also be present.

If our elected representatives were all altruistic, sensitive, introspective and honest, we perhaps would have no malfunction. But our failure to achieve this ideal is not enough to produce malfunction in a political process that contains checks and balances and recourse to the vote. There must also be defects in the correcting mechanisms. A perfectly functioning political process does not require god-like elected officials.

Furthermore, if the malfunction lies in the inadequacies of the political process in general and can be traced to such problems as inadequate recognition or representation of interests in the process, it is a far more pervasive defect than Ely recognizes. There can be political malfunctions which are not tied to the failure to represent minorities. For example, there are instances in which minorities can be overrepresented. The notion of special interest legislation or of administrative agencies "captured" by the regulated group reflects the overrepresentation of minority interests. This is a subject I consider in more depth infra notes 154-66 and accompanying text.

Even if the sole form of malfunction were the underrepresentation of minorities, that underrepresentation does not operate only in the regulation of speech and press or in the explicit classification of traditional minorities. Women who wish the freedom to have an abortion or people who wish to have sexual intercourse out of wedlock or with members of the same gender may also constitute groups underrepresented in the legislative process. In- 
tutional analysis, I turn now to consideration of the case from which Ely derives his conception of political malfunction.

\section{B. The Scope of Judicial Review: The Carolene Products Choices}

In United States v. Carolene Products Co. ${ }^{142}$ the Court applied minimal scrutiny to uphold the economic legislation before it. Carolene Products was one of several cases which signaled the end of the era of economic due process during which, for three decades, the Court had invalidated a broad range of economic legislation it felt interfered unduly with the freedom of contract. But the case is most famous for the fourth footnote in Justice Stone's opinion which suggested instances when more than minimal judicial scrutiny might be expected. ${ }^{143}$

In Ely's view this footnote captures the essence of what judicial review ought to be and, to a substantial degree, what judicial review since that case has been; it epitomizes concern with political

deed, when a state outlaws abortion or homosexuality or cohabitation, the legislation actually threatens only a small group, though it has the appearance of generality; in such a case, the legislative malfunction in question may be even less likely to be controlled by other elements in the political process than when a small group is singled out explicitly.

142304 U.S. 144 (1938).

${ }^{143}$ There may be narrower scope for operation of the presumption of constitutionality when legislation appears on its face to be within a specific prohibition of the Constitution, such as those of the first ten amendments, which are deemed equally specific when held to be embraced within the Fourteenth. See Stromberg v. California, 283 U.S. 359, 369-370; Lovell v. Griffin, 303 U.S. 444, 452.

It is unnecessary to consider now whether legislation which restricts those political processes which can ordinarily be expected to bring about repeal of undesirable legislation, is to be subjected to more exacting judicial scrutiny under the general prohibitions of the Fourteenth Amendment than are most other types of legislation. On restrictions upon the right to vote, see Nixon v. Herndon, 273 U.S. 536; Nixon v. Condon, 286 U.S. 73; on restraints upon the dissemination of information, see Near v. Minnesota ex rel. Olson, 283 U.S. 697, 713-14, 718-20, 722; Grosjean v. American Press Co., 297 U.S. 233; Lovell v. Griffin, supra; on interferences with political organizations, see Stromberg v. California, supra, 369; Fiske v. Kansas, 274 U.S. 380; Whitney v. California, 274 U.S. 357, 373-378; Herndon v. Lowry, 301 U.S. 242; and see Holmes, J., in Gitlow v. New York, 268 U.S. 652, 673; as to prohibition of peaceable assembly, see De Jonge v. Oregon, 299 U.S. 353, 365.

Nor need we enquire whether similar considerations enter into the review of statutes directed at particular religious, Pierce v. Society of Sisters, 268 U.S. 510, or national, Meyer v. Nebraska, 262 U.S. 390; Bartels v. Iowa, 262 U.S. 404; Farrington v. Tokushige, 273 U.S. 484, or racial minorities, Nixon v. Herndon, supra; Nixon v. Condon, supra: whether prejudice against discrete and insular minorities may be a special condition, which tends seriously to curtail the operation of those political processes ordinarily to be relied upon to protect minorities, and which may call for a correspondingly more searching judicial inquiry. Compare McCulloch v. Maryland, 4 Wheat. 316, 428; South Carolina v. Barnwell Bros., 303 U.S. 177, 184 n. 2, and cases cited.

Id. at 152 n.4. 
malfunction as the basis of judicial review. In the footnote's second paragraph, Ely finds judicial concern about legislation that obstructs political activities such as voting, speech, and assembly. ${ }^{144}$ In its third paragraph, he finds judicial concern about legislation directed at politically weak minorities. ${ }^{145}$

I agree that the Carolene Products footnote does relate heightened judicial review to certain forms of political malfunction. But it does not provide such scrutiny for all forms of political malfunction. In particular, it omits a form of political malfunction that has a serious claim to attention in both political theory and history: the overrepresentation of concentrated special interests. Not only does the footnote omit mention of this form of political malfunction, but, in the case before it, the Court applied a minimal standard of review to legislation that was probably the product of a legislative process subject to exactly this malfunction.

The Court's decision in Carolene Products, thus, does not recognize the need for judicial review in the full array of cases where serious political malfunction exists. As such, Ely's theory of judicial review, which bases the role of the judiciary on the existence of serious malfunction in the political process, can neither explain nor justify the Carolene Products decision. But while Ely's theory cannot evaluate Carolene Products, a more truly comparative institutional theory can. I shall consider this theme in greater depth both to aid in understanding the limitations of Ely's approach, and to explore a form of legislative malfunction-overrepresentation of certain minorities-that has not been much examined in the existing constitutional law literature. ${ }^{148}$

The legislation at issue in Carolene Products banned the interstate sale of "filled milk," or skim milk supplemented with nonmilk fats such as coconut oil. ${ }^{147}$ Congress and many state legislatures had banned this product, ostensibly because it was "adulterated" by the nonmilk additions, which provided less vitamin A than did butterfat. Although the Pure Food and Drug Act ${ }^{148}$ already required that imitations or blends be labeled as such and

144 J. Ely, supra note 15, at 76-77.

245 Id.

14 There has been some discussion of this form of malfunction in the context of the dormant commerce clause. See Tushnet, Rethinking the Dormant Commerce Clause, 1979 Wis. L. Rev. 125.

${ }^{147}$ See Filled Milk Act of 1923, Pub. L. No. 67-513, 42 Stat. 1486 (codified at 21 U.S.C. $\S \S 61-63$ (1982)).

${ }^{148}$ See Pure Food and Drug Act of 1906, Pub. L. No. 59-384, §2, 34 Stat. 768, 768 (repealed 1938). 
given a unique brand name to avoid confusion with the generic product, Congress prohibited sales of filled milk ostensibly because retail dealers were promoting the product either as identical to pure milk or as the equivalent of pure milk, and because the product also was being sold in bulk to boarding houses and ice cream manufacturers, who in turn supplied it to a public that believed it was receiving pure milk or pure milk ice cream. ${ }^{149}$

It does not take much scrutiny to see the dairy lobby at work behind the passage and enforcement of the "filled milk" act. ${ }^{150}$ Indeed, the dairy industry's efforts to employ legislation to keep "adulterated" products from grocery shelves and vending booths have a long history, extending from before Lochner $v$. New York ${ }^{\mathbf{1 5 1}}$ to the present. ${ }^{152}$ It is not too uncharitable, perhaps, to suggest that concern for the dairies' pocketbooks rather than for the consumer's health best explains the dairy lobby's efforts. In fact, though the filled milk legislation seemed to be aimed at helping consumers, it may have harmed them. They were "saved" from "adulterated" products, but only at the cost of higher prices, while the dairy industry benefited from reduced competition. ${ }^{153}$

Special interest legislation obviously is not limited to dairy products, nor to the period of the late nineteenth and early twentieth centuries. On the contrary, fear of capture of the political process by the few has been an important concern since well before the time of the framers. ${ }^{154}$ Along with the fear of monarchy and

149 See Carolene Products, 304 U.S. at 148-51 \& nn.2-3.

150 See, e.g., 67 Cong. REc. $4981-82$ (1923) (statement of Sen. Stanley that bill was a "plain attempt to utilize the dread powers of legislation to destroy one business in order to foster another"). The bill's sponsor felt obliged to note that the measure had the support of more than 30 dairy and farming groups. Id. at 3949-50 (statement of Sen. Ladd).

131198 U.S. 45 (1905).

152 For general commentary on the history of the dairy lobby, see M. Keller, Afrairs of State 413 (1977); R. Lee, A History of Regulatory Taxation 12-27 (1973); J. van STUYvenBerg, Aspects of Government Intervention, in Margarine: AN Economic and ScIENTIFIC HistoRy, 1869-1969, at 281 (J. van Stuyvenberg ed. 1969).

${ }^{133}$ See M. Keller, supra note 152, at 413-14.

${ }^{154}$ In England, concern over preference for the privileged few in the form of the grant of monopolies by the Crown was a substantial source of complaint in the seventeenth century and had its role in leading to the constitutional reforms of that century. The following passage reflects the pervasiveness of the problem:

Monopolies aroused most hostility. Often there were good reasons for protecting new industries by giving them a guaranteed market for a period of years. . . . But too often selling monopolies became a means of solving the government's fiscal problems. Monopolies were obtainable only by those with court influence. Thus the pin-makers, of humble origin, had to bribe courtiers to get a charter of incorporation. The courtiers in consequence acquired real control of the new company. In 1612 the Earl of Salisbury was receiving $£ 7,000$ a year from the silk monopoly, the Earl of Suffolk $£ 5,000$ from 
aristocracy came a fear of any governmental form that placed power within the grasp of a privileged few. The post-Revolutionary-War state constitutions reflected a suspicion of strong governors, senates, or upper houses. ${ }^{165}$ From the 1830's, state constitutional reforms showed distrust of legislatures not immediately in touch with the wishes of the populace. ${ }^{156}$ Jacksonians worried about the capture of the political process by the privileged few,

currants, the Earl of Northampton $£ 4,500$ from starch. On a humbler scale, Sir Edmund Verney had a share in one monopoly for inspecting tobacco, in another for hackney coaches and in a third 'for sealing woolen yarn before it was sold or wrought into cloth'.

$\cdots$

In 1601 a member of Parliament asked, when a list of monopolies was read out, "Is not bread there?' His irony exaggerated only slightly. It is difficult for us to picture to ourselves the life of a man living in a house built with monopoly bricks, with windows (if any) of monopoly glass; heated by monopoly coal (in Ireland monopoly timber), burning in a grate made of monopoly iron ... . He washed himself with monopoly soap, his clothes in monopoly starch. He dressed in monopoly lace, monopoly linen, monopoly leather, monopoly gold thread. His hat was of monopoly beaver, with a monopoly band. His clothes were held up by monopoly belts, monopoly buttons, monopoly pins. They were dyed with monopoly dyes. He ate monopoly butter, monopoly currants, monopoly red herrings, monopoly salmon and monopoly lobsters. His food was seasoned with monopoly salt, monopoly pepper, monopoly vinegar. Out of monopoly glasses he drank monopoly wines and monopoly spirits; out of pewter mugs made from monopoly tin he drank monopoly beer made from monopoly hops, kept in monopoly barrels or monopoly bottles, sold in monopoly-licensed ale-houses. He smoked monopoly tobacco in monopoly pipes, played with monopoly dice or monopoly cards, or on monopoly lute-strings. He wrote with monopoly pens, on monopoly writing-paper; read (through monopoly spectacles, by the light of monopoly candles) monopoly printed books, including monopoly Bibles and monopoly Latin grammars, printed on paper made from monopoly-collected rags, bound in sheepskin dressed in monopoly alum. He shot with monopoly gunpowder made from monopoly saltpetre. He travelled in monopoly sedan chairs or monopoly hackney coaches, drawn by horses fed on monopoly hay. He tipped with monopoly farthings. At sea he was lighted by monopoly lighthouses. When he made his will, he went to a monopolist. (In Ireland one could not be born, married, or die without $6 \mathrm{~d}$ to a monopolist.) Pedlars were licensed by a monopolist. Mice were caught in monopoly mousetraps. Not all these patents existed at once, but all come from the first four decades of the seventeenth century. In 1621 there were alleged to be 700 of them.

Apart possibly from beer and salt, these were not quite necessities. But monopolies added to the price of just those semi-luxuries which were beginning to come within the reach of yeomen and artisans whose standard of living was rising. They affected the daily life of hundreds of thousands of Englishmen.

C. Hil, The Century of Revolution, 1603-1714, at 31-33 (1961) (footnote omitted). This passage suggests that the mass of the populace as consumers bore the brunt of these special privileges while the few close to the Crown gained, even if the monopolies often were granted ostensibly to promote laudable ends.

${ }^{165}$ See G. WoOd, The Creation of the Amzrican Republic, 1776-1787, at 135, 237-44 (1969).

18b See M. Meyers, The Jacksonian Persuasion 255-56 (1957). 
especially organized and influential commercial interests. ${ }^{157}$ This Jacksonian populist bent also was felt in the post-Civil-War era, which saw a flourishing of political machines, graft, and special interest legislation. ${ }^{158}$ At least some of the laissez-faire philosophy of the day reflected a fear of these corrupt political processes. ${ }^{158}$ The post-Civil-War Supreme Court also evinced misgivings about legislation promoted by special interests. ${ }^{160}$

In short, fear of the few has accompanied a fear of the many throughout our history. Yet while Ely and others take account of the tyranny of the majority, which concerned the framers and still concerns us today, they ignore an equally insistent theme in our history: the overrepresentation of certain minority interests and the consequent need for protection of the majority.

I am not arguing, nor do I believe, that the Carolene Products Court was wrong not to intervene in reaction to a possible minoritarian bias. My point is that the Court's choice cannot be justified on the ground that there is no risk of a serious political malfunction in the passage of social and economic legislation such as that considered in the case. Consequently, a theory of judicial review based, as is Ely's, on reaction to political malfunction, seems inadequate to justify the Carolene Products Court's distinction between the case before it and cases such as those mentioned in the famous footnote. Neither can such a theory explain the Court's approach to judicial review thereafter.

One could argue, of course, that the form of political malfunction I have identified is either easily corrected within the political process itself or relatively unimportant. ${ }^{161}$ Under a simple conception of majority rule, it would be difficult to conceive of the overrepresentation of minority interests at the expense of the majority. Consumers outnumber and have more votes than the producers who desire to make monopoly profits at their expense. How do the fewer votes command the larger share of political attention?

To answer this question, one must observe an important char-

${ }^{167}$ See id. passim.

${ }_{168}$ See M. Keller, supra note 152, at 167, 242-47, 257, 271, 522-25.

${ }^{150}$ See M. MEYERs, supra note 156, at 12.

${ }^{280}$ Justice Field, who was a major actor in shaping the movement toward the strong intervention of the Lochner era, apparently was strongly influenced by his perception of the corrupting effect of special interests in the commercial legislation of the time. See McCurdy, Justice Field and the Jurisprudence of Government-Business Relations: Some Parameters of Laissez-Faire Constitutionalism, 1863-1897, 61 J. AM. Hist. 970, 976-77, 981 (1975).

${ }^{161}$ Thus, one might argue that the various factions compete in the political "marketplace" and that the political process, like the ideal market, yields optimal solutions. For a summary, and a critique of this pluralist position, see T. LowI, supra note 2, at 41-54. 
acteristic of the majority involved in this sort of legislation: each individual consumer has but a small stake in each piece of legislation. It is the aggregate impact on all consumers of a particular statute and the aggregate impact on each consumer of all such legislation that can be substantial. Each statute is, in effect, an excise or sales tax on a particular consumer good. When aggregated for all the goods and services consumed by any consumer, the impact of these implicit sales taxes can be great. ${ }^{162}$ Yet a consumer's stake in any single piece of such legislation is so low that it does not justify the consumer's spending the resources needed to monitor the political process, determine whether the legislation is unfavorable to that consumer, present counter arguments, or organize political efforts. The interests of producers, by contrast, may be lower in the aggregate, but because these interests are more concentrated and more easily recognizable by the producers, they lead to more and better organized political activity. ${ }^{163}$ As a consequence, the interests of producers will receive disproportionate weight in the legislative process and the interests of consumers will be accordingly underrepresented.

On both historical and theoretical grounds, then, overrepresentation of concentrated interests appears to be a serious malfunction in our legislative process. If, as Ely's theory suggests, the existence of a serious political malfunction is a sufficient ground for judicial intervention, then the Carolene Products Court should not have employed minimal scrutiny in the case before it and should have added a fourth paragraph to its famous footnote, adding this malfunction to its catalogue. From a comparative institutional standpoint, however, the existence of political malfunction is not a sufficient basis for judicial intervention. There are indeed quite plausible institutional grounds for the Carolene Products Court's choice to provide only minimal scrutiny to cases like the one before it. A staggering task would confront a judiciary that intervened in all instances in which a dormant majority was ex-

182 The aggregate effect of the seventeenth-century monopolies in England is reflected in the passage quoted supra note 154. Modern special interest legislation is perhaps more subtle, but it is also more pervasive. Although seventeenth-century monopolies were apparently not granted on necessities (aside from beer and salt), see supra note 154, the "filled milk" legislation itself suggests that twentieth-century special interest legislation affects even the most basic products.

${ }^{163}$ For an economist's version of this analysis, see Stigler, The Theory of Economic Regulation, 2 BerL J. Econ. \& Mamt. Scr. 3 (1971). The problem need not be limited to defects in the achievement of efficient resource allocation. The underrepresentation of consumers is also a serious obstacle to equality in the distribution of resources or in the treatment of individuals, since it is the poor who are most likely to suffer here. 
ploited by an active, concentrated special interest, because the potential for such a configuration of interests is pervasive, not limited even to economic regulation. ${ }^{164}$ Every legislative issue, from economic regulation to the provision of public services to the control of the environment, stimulates politicking by groups. In many instances, these organized efforts may only be feasible on one side of the issue, thereby creating the defect in question.

As I noted previously, ${ }^{165}$ a defect in the legislative process means that legislatures have a tendency to legislate more favorably to the overrepresented interest than they would were the process nondefective. It certainly does not follow, however, that a nondefective legislature would produce no legislation favorable to that interest. Considering the broad range of legislative issues that might be infected by special interest bias, the judiciary does not have the luxury of strictly scrutinizing all legislation which may be tainted.

One can see the problems confronting the Court particularly well in the context of economic regulations. Even among free market advocates, there are few who argue that all regulation of market activity is bad (whatever one's criteria of badness). While many may argue that there is a tendency toward overregulation because of the unchecked, or underchecked, desires of producers to limit competition, it hardly follows that a well-balanced or perfectly functioning political process would never regulate economic activity. Serious informational problems, external effects on third parties, monopolistic elements, as well as concern about wealth distribution and its impact, may prompt legislative intervention. It is extremely difficult for any outside observer to determine whether the justification for intervention is sufficient.

Such difficulty does not derive simply from a lack of technical expertise. It is common enough for constitutional scholars to make reference to the Court's lack of expertise about economic affairs, as though nine economists in robes would be ideal decisionmakers. Experts can provide a list of considerations, but the most difficult task is to determine the weight each consideration should have in the final decision. It is not an easy task, for example, to decide whether filled milk should be prohibited. Even if a court were able

${ }^{164}$ For example, federal and state taxpayers usually suffer a per capita loss of only a few cents from a tax provision that profits a special interest. Again, although the aggregate impact on taxpayers as a whole is significant, the taxpayer's position is likely to be poorly represented because of his low per capita loss and lack of organization.

${ }^{185}$ See supra text accompanying note 138. 
to identify the degree to which safety and health would be improved, it would have to find a method for.weighing the value of that improvement against the decline in consumer buying power that would result from prohibition. The method of the market is to look to the preferences of consumers as revealed in transactions for the items involved. As we have noted, however, that market too may be severely defective. Similarly, the method of the political process is to look to voting or lobbying as it affects the views of legislators desiring to retain office. But as we have also noted, that process may be defective if one interest is overrepresented. Nonetheless, if the judiciary is to substitute for either of these two mechanisms, it must find a method of its own.

The era of economic due process taught us important lessons about the institutional limitations of the judiciary-lessons that may explain and justify the Carolene Products choice to limit judicial review of economic legislation severely and to omit from the catalogue of footnote four the problem of overrepresentation and special interests. In Lochner $v$. New York ${ }^{\mathbf{1 6 6}}$ and subsequent cases, ${ }^{167}$ the Court employed criteria that mimicked notions of market failure or malfunction: monopoly, incapacity, and impacts on third parties not involved in the particular contract or market transactions. The Court apparently thought that such criteria provided a workable means for it to identify allowable legislative interventions into the market. But as any student of introductory economics knows, these effects are likely to exist in virtually any setting. Product differentiation, incomplete or imperfect information, and externalities are pervasive. The market-like all institutions-is always and inevitably imperfect.

During the Lochner era, the Court took upon itself to decide when these imperfections in the market were severe enough to justify government intervention. The Court assumed the task of making policy decisions over a broad range of social issues, thereby inviting the dense and voluminous submissions introduced by Louis Brandeis $^{188}$ in Muller $v$. Oregon. ${ }^{169}$ The Brandeis brief, with its extensive survey of socioeconomic data and opinion, was the logical response to the broad-based task undertaken by the Court ${ }^{170}$-a

188198 U.S. 45 (1905).

${ }^{167}$ See infra note 171 and cases cited therein.

${ }^{1 e s}$ See Brief for Defendant in Error, Muller v. Oregon, 208 U.S. 412 (1908), reprinted in 16 Landmark Brigfs and Arguments of the Supremb Court: Constitutional Law 63

(P. Kurland \& G. Casper ed. 1975).

189208 U.S. 412 (1908).

170 See Doro, The Brandeis Brief, 11 VAND. L. Rev. 783, 789-90 (1958). 
task at which it tried its hand for more than three decades. The results seemed to show the strain. There were abrupt and unexplained shifts in the formulation and application of central doctrines, doctrines that the Court itself admitted were virtually impossible to define and apply. ${ }^{171}$

The dramatic economic fluctuations of the 1930's-bringing with them an outpouring of economic legislation along with indications that market imperfections were perhaps more complex and more pervasive than the Court had previously thought-signaled the end of its efforts. The legislative process need not have looked any more trustworthy than it ever had to explain this change in

${ }^{171}$ In Lochner itself, the Court invalidated maximum-hour legislation in the baking industry although it had shortly before approved such legislation with respect to the mining industry in Holden v. Hardy, 169 U.S. 366, 396-97 (1898). Within a few years, it made an exception to the invalidity of maximum-hour legislation for instances where it applied particularly to women in Muller v. Oregon, 208 U.S. 412, 421-23 (1908). Not much later, the Court allowed maximum-hour legislation virtually across the board without even noting that it was overruling Lochner. Bunting v. Oregon, 243 U.S. 426, 437-39 (1917).

Over the same period the Court's decisions on the related subject of the validity of minimum-wage legislation showed the opposite progression. The Court had upheld federal minimum-wage legislation in 1916, Wilson v. New York, 243 U.S. 332, 359 (1916), upheld state minimum-wage legislation in 1917, Stettler v. O'Hara, 243 U.S. 629 (1917) (per curiam), aff'g by an equally divided court 69 Or. 519, 139 P. 743 (1914), and Simpson v. O'Hara, 70 Or. 261, 141 P. 158 (1914), invalidated federal minimum-wage legislation in 1923, Adkins v. Children's Hospital, 261 U.S. 525, 560-62 (1923), and appeared to do the same for state legislation under the authority of Adkins v. Children's Hospital, in 1925 and 1927. Donham v. West-Nelson Mfg. Co., 273 U.S. 657 (1927) (per curiam); Murphy v. Sardell, 269 U.S. 530 (1925) (per curiam).

The trend for the Court's treatment of minimum-wage legislation was not only inconsistent with the pattern of maximum-hour cases, it was also apparently confusing. When, in 1937, the Court finally upheld minimum-wage lows (after apparently invalidating a similar law the previous year in Moorehead v. New York ex rel. Tipaldo, 298 U.S. 587, 618 (1936)), the Washington statute it upheld had been in existence for twenty years. See West Coast Hotel Co. v. Parrish, 300 U.S. 379, 399-400 (1937).

During the entire era, the Court limited regulation of prices and rates to businesses "affected with a public interest." From its inception in the pre-Lochner case of Munn v. Illinois, 94 U.S. 113, 125-26, 133-35 (1877), to its death nearly 60 years later in Nebbia v. New York, 291 U.S. 502, 536-39 (1934), this central concept remained a mystery. The Court flirted with the idea of monopoly as a defining element, but it did not consistently adhere to this criterion. See Nebbia, 291 U.S. at 538. The test was adopted in Munn, virtually abandoned in Brass v. North Dakota ex rel. Stoeser, 153 U.S. 391, 402-04 (1894), questioned in Williams v. Standard Oil Co., 278 U.S. 235, 239 (1929), and briefly resurrected in Tagg Bros. v. United States, 280 U.S. 420, 438-39 (1930). For a time, the Court also spoke of a business's impact on the general public, see Munn, 94 U.S. at 126, but it eventually abandoned this unwieldy concept, see Tyson \& Brother v. Banton, 273 U.S. 418, 430 (1927). The Court found itself regularly admitting that the "public interest" test was difficult to explain and apply, see, e.g., Tyson, 273 U.S. at 430; Ribnik v. McBride, 277 U.S. 350, 355 (1928), but it kept trying to employ it. Finally, in Nebbia, 291 U.S. at 536, the Court conceded that there could be no "closed class" of businesses "affected with a public interest"; all businesses of any importance affect the public. 
the Court's stance. The Court need only have been less sure than before that questions about the propriety of governmental intervention in the market could be framed to match the judiciary's limited resources, or that the judiciary was obviously superior to the imperfect political process at structuring regulation of the market.

This brief treatment of the end of the era of economic due process suggests that the Court's choice, evident in Carolene Products, to scrutinize economic legislation less rigorously than it had during the Lochner era cannot be assessed fully without regard for both the substantive goals of the decisionmakers, and the relative institutional capacities of the political and judicial branches. ${ }^{172}$

172 I have suggested that the rise and fall of economic due process may reflect perceptions of relative institutional efficacy. The Court of the Lochner era seems to have reflected concerns about legislative malfunction both in the form of underrepresentation of the propertied minority and in the form of overrepresentation of concentrated commercial interests. The era may have ended solely because, in the 1930's, the Court changed its views about which malfunctions existed or were important. There is certainly evidence that the Roosevelt Court was more concerned with racial and ethnic intolerance in the political process than with intolerance or favoritism resulting from economic power. For a comprehensive examination of social trends in the 1930's as reflected in the views of some of the Justices, see Bixby, supra note 80 , at 761-79.

It is not as clear, however, that the members of the Roosevelt Court became wholly sanguine about the dangers of special interest legislation. Roosevelt-era Justices such as Douglas and Black, of course, appeared to be quite unconcerned about economic legislation even when the marks it bore of special interests were quite clear. See, e.g., Williamson v. Lee Optical, 348 U.S. 483 (1955) (Douglas, J.); Ferguson v. Skrupa, 372 U.S. 726 (1963) (Black, J.). But such indifference does not necessarily signal a lack of distrust of the legislative process. The experience of the economic due process era, after all, also taught strong lessons about the limitations of judicial ability. Those lessons, rather than a new-found faith in economic legislation, may explain this "hands-off" stance.

In fact, there are indications that the judiciary has continued to harbor a distrust of special-interest economic legislation. In Morey v. Doud, 354 U.S. 457 (1957), for example, the Warren Court examined Illinois legislation that had imposed financial responsibility requirements on businesses issuing money orders but had exempted one named company, American Express, from the requirement. This case represents the sole instance since the 1930's in which the equal protection clause has been used to strike down special-interest economic regulation-a fact that reflects, perhaps, the flagrancy of the legislation. A single entity of significant stature and financial resources received explicit special treatment. It is difficult not to distrust such legislation.

As the history of economic due process suggests, however, a manageable judicial reaction to that distrust is difficult. In City of New Orleans v. Dukes, 427 U.S. 297, 306 (1976), the Burger Court overruled Morey. In Dukes, the Court was asked to invalidate a New Orleans ordinance which excluded pushcart food vendors from the French Quarter but which grandfathered in those who had operated for more than eight years. The lower court had relied on Morey in invalidating the law. Dukes v. City of New Orleans, 501 F.2d 706, 711-13 (5th Cir. 1974). The Supreme Court, however, retreated to its usual deferential standard, see, e.g., Ferguson v. Skrupa, 372 U.S. 726, 732 (1963), for reviewing economic regulation. City of New Orleans v. Dukes, 427 U.S. 297, 303-04. In principle, Morey could have been distinguished on institutional grounds: the one party exempted from the statutory re- 
Members of the Carolene Products Court may have been motivated by any number of objectives ranging from more equality in the allocation of material resources, or more equality in the treatment of individuals, or more efficiency in the allocation of resources, to greater consistency with the will of the people or the will of the framers. But whether the Court's decision in Carolene Products serves any of these goals depends in significant part on whether the allocation of decisionmaking power among institutions was correct. Only careful attention to institutional realities will yield an answer to that latter question.

The Carolene Products footnote is a good place to begin a careful analysis of relative institutional competence. In those few words, a court struggling with the confines of judicial review pro-

quirement was an entity so large and sophisticated as almost to compel the conclusion that its interest had been given undue weight in the legislative process. Yet such a distinction only serves to emphasize the continuous nature of the spectrum of potential special-interest influence and the ease with which federal courts, unable to draw administrative lines, might be drawn into reviewing the broad range of economic regulations. The lower court in Dukes no doubt suspected legislative malfunction, see Dukes, $501 \mathrm{~F} .2 \mathrm{~d}$ at 713, and the Court may well have shared that suspicion, but it may also have seen the broader implications of strictly scrutinizing the statute in question.

That the Burger Court, despite Dukes, is not itself immune from the temptation to strike at special-interest legislation can be seen in its treatment of commercial speech. The leading case here is Virginia State Bd. of Pharmacy v. Virginia Citizens Consumer Council, Inc., 425 U.S. 748 (1976), decided the same year as Dukes. The Court invalidated a Virginia law that prohibited pharmacists from advertising prescription drug prices. Because it saw the case as presenting a first amendment problem, the Court's close scrutiny of the legislation is not surprising. But political speech, or even cultural speech, was not involved. Therefore, the case cannot easily be placed within Ely's political process rationale or even within the broader individual self-realization rationale. Notice, however, that the legislation was a garden variety of economic regulation, a classic example of a restriction on competition. The Virginia Pharmacy dissent, and many commentators have suggested that the case is a throwback to economic due process. 425 U.S. at 784 (Rehnquist, J., dissenting). See, e.g., Baker, Commercial Speech: A Problem in the Theory of Freedom, 62 IowA L. REv. 1, 4-5 \& n.22 (1976); Coase, Advertising and Free Speech, 6 J. LeGat. Stud. 1, 32-34 (1977); Jackson \& Jeffries, Commercial Speech: Economic Due Process and the First Amendment, 65 VA. L. REv. 1, 25-41 (1979).

As Morey and Virginia Pharmacy suggest, in neither the Warren nor the Burger years has the Court entirely lost its distrust of economic regulation. But the mode by which the recent Court has entered the arena of commercial regulation deserves special emphasis. It has sought to limit the range of economic regulation the judiciary will need to review. The first amendment aspect of Virginia Pharmacy, for example, provides a line of demarcation. Even limiting itself to speech cases, however, the Court faces a considerable range of commercial regulation. In subsequent cases, accordingly, the Court has sought to establish the boundaries of the Virginia Pharmacy doctrine. See, e.g., Central Hudson Gas \& Elec. Corp. v. Public Serv. Comm'n, 447 U.S. 557, 562-66, 569-71 (1980) (advertising by public utility protected); Friedman v. Rodgers, 440 U.S. 1, 15-16 (1979) (use of trade name by optometrist not protected); Bates v. State Bar, 433 U.S. 350, 383-84 (1977) (price advertising by lawyers protected); Linmark Assoc., Inc. v. Willingboro, 431 U.S. 85, 96-97 (1977) (real estate "for sale" signs protected). Virginia Pharmacy may yet go the way of Morey $v$. Doud. 
vided insights about that struggle. Ely, moreover, has expanded upon these insights to provide an institutionally-based theory of judicial review. He correctly perceives that concern about the limits of the political process is a basic theme of constitutional analysis, evident in the Constitution and in its interpretation by the Warren Court. Through this lens he offers insights into many facets of constitutional law.

But Ely stops too soon. The Carolene Products footnote, whatever its value, is incomplete. It identifies defects in the political process that are important but that do not reflect the complete range of important potential political malfunctions. That the footnote did not provide an exhaustive list is understandable given its purpose. It was meant to suggest in only a preliminary way certain circumstances in which the judiciary might expend its limited resources in close examination of legislation. ${ }^{173}$ It may be that after careful institutional comparison Ely's basic conclusions will hold. It may turn out that the judiciary should react only to the two forms of political malfunction he names and in only the manner he indicates; perhaps he is correct that the judiciary should not concern itself with either the regulation of commerce or the regulation of morals. But if Ely is correct, it will not be because serious political malfunction is obviously absent from either of these excluded areas or because the judiciary is self-evidently the decisionmaker of choice for the vast range of issues to be decided in the areas he allocates to them. Any such conclusions must rest on an institutional comparison more complete than his theory of judicial review gives us.

\section{The Role of Judicial Reasoning: The Approaches of Harry Wellington and Michael Perry}

Several constitutional scholars, in an effort to define the scope of judicial review, emphasize the disinterested, contemplative, and neutral nature of judicial decisionmaking in contrast to the passionate, self-interested hurly-burly of the legislative process. To observe as much is to make an institutional argument. From these institutional generalizations, these authors draw broad conclusions about the appropriate allocation of government decisionmaking. They assign moral or principled inquiry to the judiciary, and policy or expedient inquiry to the political process. Such an approach, I 
believe, proves inadequate as a means to understanding or evaluating constitutional law. Issues do not divide easily along the lines suggested. Even if they did, there is little reason to believe a priori that the proposed institutional configuration would be superior. The characteristics attributed to the judiciary seem, as generalizations, sensible, but the leap from these attributes to the functions suggested is treacherous.

Dean Harry Wellington's work on constitutional theory spans two generations. His earlier work with Alexander Bickel stands as an important attempt to find a theory of judicial review that recognizes both the complexity of substantive decisionmaking and the existence of problems in the legislative process. ${ }^{174}$ In his more recent work, he has argued that the judiciary should be assigned the task of discovering principles derived from conventional morality. He offers a distinction between the search for these principles and the determination of policy, and associates these two tasks with a general perception of institutional attributes:

If a society were to design an institution which had the job of finding the society's set of moral principles and determining how they bear on concrete situations, that institution would be sharply different from one charged with proposing policies. The latter institution would be constructed with the understanding that it was to respond to the people's exercise of political power; in America, that means interest group politics. The former would be insulated from such pressure. It would provide an environment conducive to rumination, reflection, and analysis. ${ }^{175}$

Reacting to criticism by Ely, ${ }^{176}$ Wellington has restated his position, placing even greater emphasis on the shortcomings of the political process:

The costs of uniting present and past should be acknowledged: our predecessors too were imperfect. Nevertheless, a governmental structure that fails to unite a nation's present with its past necessarily fails to preserve values to which its citizens may attach considerable weight. It fails to make a contemporary effort to understand what we have been or have wished as a people to become, and thus it fails to give effect to

174 See Bickel \& Wellington, supra note 18.

178 Wellington, Common Law Rules and Constitutional Double Standards: Some Notes on Adjudication, 83 YALE L.J. 221, 246-47 (1973) (footnote omitted).

${ }^{178}$ See J. ELY, supra note 15, at 63-64. 
what might be called the moral ideals of the community. Those ideals cannot be understood by the bureaucracy, the special pleaders, and the congressional staffers. Theirs is a tunnel vision, and the tunnel vision of one is not offset by that of the others. Nor would these ideals be given adequate voice in a simple majoritarian government where the passionate and self-interested concerns of the moment were too easily accorded sovereignty. ${ }^{177}$

Professor Michael Perry has recently presented a theory of the role of judicial review in human rights cases that, like Wellington's, stresses the reflective, contemplative, and neutral attributes of the judiciary:

I will begin explaining my justification for noninterpretive review in human rights cases with some fairly uncontroversial observations about comparative institutional competence. In recent generations, certain political issues have been widely perceived to be fundamental moral issues as well-issues that challenge and unsettle conventional ways of understanding the moral universe and that serve as occasions for forging alternative ways of understanding. In twentieth century America there have been several such issues: distributive justice and the role of government, freedom of political dissent, racism, sexism, the death penalty, and human sexuality. Our electorally accountable policymaking institutions are not well suited to deal with such issues in a way that is faithful to the notion of moral evolution and, therefore, to our religious understanding of ourselves.

Executive and legislative officials tend to deal with fundamental political-moral problems, at least highly controversial ones, when they confront such issues at all, by reflexive reference to the established moral conventions of the greater part of their particular constituencies. They refuse to see in such issues occasions for moral reevaluation and possible moral growth.

Elected officials function that way principally because for most of them few, if any, values rank as high as incumbency. ...

Not that a concern for remaining in office is always inappropriate. That concern is of course what makes electoral ac-

${ }^{177}$ Wellington, The Nature of Judicial Review, 91 YALE L.J. 486, 494 (1982) (footnote omitted). 
countability work as well as it does to keep our representatives in tune with the polity. However, a concern for remaining in office is not a particularly good way to keep faith with the notion of moral evolution, which requires ongoing, vigorous reevaluation of established moral conventions. Indeed, "[l] egislators have become astute at turning a deaf ear to highly visible issues on which they do not want to gamble their political lives." Over time, the practice of noninterpretive review has evolved as a way of remedying what would otherwise be a serious defect in American government: the absence of any policymaking institution that regularly deals with fundamental political-moral problems other than by mechanical reference to established moral conventions. ${ }^{178}$

Perry's institutional approach is much like Wellington's. Both view political officials as being substantially motivated by their self-interested wish to be re-elected. As a consequence, such officials are "reflexive" decisionmakers, simply reacting to the desires and preferences of their constituents-desires and preferences that do not necessarily accord with moral principles.

It is difficult at the outset to see how Wellington defines "principle" and "policy," or how those categories relate to any feasible division of decisionmaking responsibility. Principle seems to refer to basic precepts or constant general maxims. ${ }^{179}$ Policy, by contrast, appears to be short-term and narrowly focused; it is more expedient, more responsive to the needs of the moment. ${ }^{180}$ Precisely what Perry means by the associated conceptions of moral evolution and the "religious" sense of American self-understanding is even more difficult to ascertain. He would probably admit that the meaning is vague. I think he is attempting to capture what each of us feels-that there is a sense of right and wrong which is basic, albeit difficult to articulate and which evolves or changes over time-and is employing this sense to define "moral issues."181

Whatever the uses for these distinctions elsewhere, they will not serve as a sufficient guide to describe or evaluate the allocation of societal decisionmaking. Even if there were a clear match between principle and the abilities of the judiciary, on the one hand,

178 Perry, Noninterpretive Review in Human Rights Cases: A Functional Justification, 56 N.Y.U. L. REv. 278, 293-94 (1981) (footnote omitted) (quoting Traynor, The Limits of Judicial Creativity, 63 Iowa L. Rev. 1, 8 (1977)).

179 See Wellington, supra note 175 , at $245-46$.

180 See id. at 237.

181 See Perry, supra note 178, at 283-93. 
and between policy and the abilities of the legislative process, on the other (I will suggest that there is not), one is still left to divide the real world between social issues that engage questions of "principle" or "moral evolution" and those that engage questions of "policy" or "expediency."

Perry offers several examples of moral issues. In the passage I have quoted, he lists distributive justice, political dissent, racism, sexism, the death penalty, and human sexuality. These are obviously important social issues about which, with the possible exception of the first, the courts have had quite a bit to say. But is this list of fundamental political-moral problems complete? Questions of war and peace, which classically raise fundamental moral-political problems, are conspicuously absent from the list. Much of the "political dissent" with which Perry is concerned has been related historically to the moral and political justification of a given war or even of war in general. The issue of nuclear war, its control, and its meaning for national and international morality, for example, continues to strain our national sense of right and wrong as it has for several decades. At least as a matter of description, however, Perry could not list this issue because it is not one into which the judiciary has been much or often willing to intervene. ${ }^{182}$ As we have seen, the courts have been reluctant to address questions of war and peace even when racism has been involved. ${ }^{183}$ One might argue, of course, that such unwillingness to intervene reflects the fact that the political process has generally handled questions of war and peace well, but I can think of few arguments so likely to meet with a skeptical response. One might ultimately conclude that the political branches may be best suited to decide these issues, but their history of war-related decisions is nevertheless far from ideal.

The shortcomings of the distinction offered by Wellington and Perry are evident even when one focuses on matters that seem quintessentially within the legislative responsibility. It is difficult to pick out many important issues which do not involve basic principles or weighty moral issues. Control of unemployment and inflation, expenditures on health and education, immigration policy, control of the environment, and the location and quantity of housing are but a few of the issues that engage questions of principle and basic values. Yet, as a general matter, responsibility for these

${ }_{182}$ See, e.g., Mora v. McNamara, 389 U.S. 934 (1967) (denying certiorari in suit seeking a declaratory judgment that American military actions in Vietnam were unconstitutional).

${ }^{183}$ See supra text accompanying notes 64-82 (discussing Korematsu v. United States, 323 U.S. 214 (1944)). 
issues lies with the legislative process. The judiciary has played no role in most of these decisions, a minor role in some, and a major role in very few.

Whatever is meant, then, by issues of principle or morality, there is no obvious correlation between these issues and the traditional allocation of decisionmaking responsibility between the judiciary and the political branches. Wellington and, especially, Perry may wish to make major alterations in the allocation of decisionmaking authority, but, unless they wish to allocate virtually all decisions to the judiciary, they must better distinguish questions of morality or principle from the presumably much larger set of questions controlled by the legislature.

Having observed this threshold difficulty in the theories of Wellington and Perry, I now can turn to the institutional arguments they make. Assuming that one could or would want to make a distinction between issues that engage questions of principle or morality and those that engage questions of policy or expediency, is it clear that the judiciary should be given primary responsibility for the former?

Wellington and Perry argue that the judicial process is contemplative, disinterested, and neutral, i.e., it reasons. They see the legislative process, by contrast, as driven by passion and self-interest. Legislators do not have the time, protection, and perhaps even training to reason or contemplate. Of course, these are generalizations, but even if they were universally true, they would not in themselves yield any institutional answers.

Contemplation, reasoning, dispassionate consideration, and the desire to consider the long view are fine attributes. If voters and their elected representatives consistently functioned in this way, many defects in the legislative process might well be eliminated. But Wellington and Perry do not propose to make the legislature more contemplative; they propose to substitute a more contemplative judiciary for the legislature. Societal decisionmaking thereby gains, to be sure, contemplation and reason, but it loses a basic measure of public will, desire, and reaction available in the legislative process.

The choice presented by Wellington and Perry is analogous to the choice between central planning and a market allocation of resources. The actors in the market are self-interested. They can be described as driven by passion, ignorance, and shortsightedness. Consequently, the results of market allocation can fail to take account of important factors, thereby injuring third parties or even the market actors themselves. These market imperfections provide 
the impetus for considering such alternative modes of allocating resources as central planning.

In a system of central planning the actors are assumed not to be short-sighted or self-interested; contemplation and reason in service of the general public are supposedly the system's features. But even if a central planning scheme fulfilled these ideals, it would still be missing an important element. In the hurly-burly of market activity, despite the shortsightedness and because of selfinterest, wants and desires are revealed. The information gained is not just a shopping list of goods and services preferred. It puts weights on these desires and provides a simple index-relative prices-by which to assess relative demand. The actors in the market do not intend to produce this information or control their own desires by variation in supply and demand. The affirmative features of the market-to the extent they exist-are by-products of the interaction of self-interested people.

Though the market has serious defects or imperfections-as does the political process-greater cor:templation, reason, and disinterestedness are not cost-free. If one abandons the market or the political process, information about the wishes of the public as citizens, consumers, or moral individuals must be obtained in some other manner. ${ }^{184}$ It generally may be correct that moral truth, moral evolution, and basic conventional morality are not faithfully embodied in the output of the political process. To say as much, however, is merely to recognize imperfection, which alone advances discussion little in a world of only imperfect alternatives. The political process may be highly imperfect and yet still superior to any other alternative as the instrument of society's moral evolution. ${ }^{185}$

Perry and Wellington have extrapolated from a sensitive perception of individual moral evolution to a far more tenuous perception of aggregate moral evolution. That the judiciary is the social institution with the characteristics closest to those associated with better individual decisionmaking may explain its attractiveness to these commentators. But they are not analyzing individual evolu-

186 For an excellent treatment of the shortcomings that derived from the substitution of expertise for the political process in the Progressive Era, see Sandalow, The Distrust of Politics, 56 N.Y.U. L. Rev. 446 (1981).

${ }^{185}$ Perry's emphasis, and to a lesser extent Wellington's, on the intentions and motivations of individual actors may represent a common analytical fallacy. Political actors, like market actors, may not intend to do good or to act efficiently or fairly, but to the extent that we are concerned, not with their intentions but with the aggregate effects of those intentions, the end result might be the good sought, even if we suppose that the actors never intended to do that good. 
tion and individual decisionmaking. They are analyzing societal evolution and societal decisionmaking, and the judiciary has at best a limited sense of the perceptions and feelings of the rest of society. Personal introspection may be fine for personal decisions; it may even be a better means of making some social decisions than a severely defective political process, but it is not obviously the best means-certainly not without regard to the degree and kind of defect in the political process or without regard to the type of issue or value involved.

There is some ambiguity in analyses, like Wellington's, that rest upon the principle/policy distinction as to whether the distinction is meant as advice to the judiciary on how it should decide or advice on whether it should decide. An inquiry into how judicial decisions are, or should be, made is a perfectly legitimate analytical endeavor, but it is important to realize that such an inquiry does not directly address the choice that must be made about which institution, the judiciary or the political branches, is best able to make a given decision. It may be that it is wiser for the judiciary to decide what it decides on the basis of principle (longterm, traditional maxims) rather than on the basis of policy (predictions about the immediate, practical consequences of a decision on the behavior of societal actors). To say as much, however, is not to indicate that the judiciary is superior to the political branches as the arbiter of principle. Again it is important to stress that reasoning, moral, judicial, or otherwise, is one means, but not the only or necessarily the best means to manifest basic principles.

Perry and Wellington may be correct that greater neutrality and, to a lesser extent, contemplativeness are attributes which make the judiciary an attractive alternative in some settings. My objections to their analyses arise from their belief that these advantages are general and determinative, and can themselves serve as the basis for a correct allocation of institutional responsibility. Once we understand clearly how the decisionmaking ability of the political branches varies depending on the issue in question, it may be appropriate to conclude that certain societal issues are best allocated to the judiciary for decision. But the attributes of the judiciary identified by Wellington and Perry do not alone provide a basis for such an allocation.

IV. The Role of Fundamental Values and the InTent of the

Framers: The Approaches of Laurence Tribe and Raoul BERGER

Institutional analysis is demanding; it requires care and effort 
and yields results slowly. There are two general strategies for constitutional analysis that seem at least partially to escape these difficulties. One emphasizes the search for fundamental values or goals; the other emphasizes the intentions of those who framed and ratified the particular provisions of the Constitution. Although these positions are often seen as polar opposites, ${ }^{186}$ they have one important feature in common: both deny that comparative institutional analysis has a central role in constitutional law. It is important, therefore, to establish whether, and the extent to which, each approach offers an adequate escape from the task of institutional comparison.

\section{A. Fundamental Value Analysis}

Most constitutional scholars see some role for the identification of values, interests or goals in constitutional analysis. I am no exception. The question here is the extent to which the search for fundamental values can explain or evaluate constitutional law without recourse to institutional analysis.

Professor Laurence Tribe is the most outspoken critic of institutional analysis and of those who stray from the search for fundamental interests. Tribe's position may be observed most conveniently in a recent article in which he severely criticizes "processbased" constitutional theories in general and the theory of John Hart Ely in particular. ${ }^{187}$ Tribe argues that the essence of the Constitution lies in the substantive values it embodies rather than in its institutional choices. He begins by pointing to three basic substantive values present in the Constitution, "[r]eligious freedom, antislavery, [and] private property."188 These values are embodied in such provisions as the first amendment establishment and free exercise clauses, the thirteenth amendment, and the contract and compensation clauses. ${ }^{189}$

If the significance of these provisions is thus said to be substantive, then one is obliged to ask what it means to call something substantive. Stating that the Constitution embodies a particular value does not explain why that value is embodied in the particu-

${ }^{186}$ See J. ELy, supra note 15, at 1, 43.

187 See Tribe, supra note 99, at 1063-65.

188 Id. at 1067.

188 Id. at 1065. With the possible exception of the compensation clause, Ely also concedes that these provisions manifest substantive commitments. See J. ELY, supra note 15, at 91-101. With respect to these clauses, Tribe and Ely find one of their few grounds for agreement. 
lar form or determine its limits and its application in particular instances. Take, for example, the compensation clause. ${ }^{190}$ It is not difficult to concede that this clause relates to the protection of private property. Yet, to identify the protection of private property as a goal does not, by itself, carry the understanding of the compensation clause very far. Whatever one means by the protection of private property, it is difficult to evaluate or explain the clause without some consideration of the relative merits of alternative, imperfect decisionmakers who may be assigned the task of protecting private property-without, in other words, some institutional analysis.

Accepting for the moment Tribe's claim that the compensation clause embodies a choice to protect private property, one is faced with the realization that there are many conditions under which forcing the government to compensate an individual property owner could harm private property generally. One can easily imagine the need to build a dam to protect private land from flood, or a courthouse or police station to aid in the protection of legal rights to physical assets. But such projects could be thwarted in some circumstances by the costs associated with the requirement to compensate. For example, if government were required to compensate every private interest that might suffer adverse economic effect as a result of the creation of an improved highway route to replace an old one, the cost of creating a more socially efficient plan might be prohibitive-to the damage of all business, realty, or other private interests that might stand to benefit from a more effective highway layout. As a general matter, since protection of private property can as often require the force of the state as its forbearance, it is by no means obvious that requiring the payment of compensation by the government would always be the preferred means to protect private property.

In fact, because the compensation clause has raised many questions of interpretation, additional institutional complexity has been added. The substantive issues of when, if, and to what extent compensation is to be paid were not finally resolved by the particular wording of the fifth amendment. The judiciary has taken upon itself a significant part in defining the scope of just compensation. The compensation clause, then, has had the effect of removing an important set of decisions from the legislative process and allocating them to the judiciary. How can one know a priori that control

180 "[P]rivate property [shall not] be taken for public use, without just compensation." U.S. Const. amend. V. 
of the state through a complex scheme evolved by the judiciary better protects private property than would an unencumbered legislature or a legislature controlled by more precise and definite terms in the document itself? One can understand or justify removal of the compensation decision from the legislative branches and its allocation to the judiciary only by considering the relative abilities of these alternative institutions. If the nation were today to sit as a new constitutional convention, and all agreed that protection of private property was paramount, would it opt for a fixed definition of compensation that might be outrun by unanticipated future events, thereby possibly disserving its goal of protecting private property? Would it allow the legislative process, or any part of it, to make the compensation choices and risk the problems arising from majoritarian rule or other shortcomings of the political process? Would it allow the judiciary to make these choices even though it would generally not allow such an institution to make such trade-offs? These institutional questions are central to our notion of just compensation as a substantive right, and they are not answered by simply postulating the protection of private property as a substantive goal.

The contracts clause ${ }^{191}$ raises similar questions. Again, one can conceive of instances in which contracting, or "the ability to arrive at binding agreements," 192 would be promoted by legislative action that altered obligations or contracts. A significant and unexpected shift in economic circumstances might make the fulfillment of contractual obligations inconsistent with the desires and expectations of the parties and might create disincentives to contracting. Arguably, a common law court could deal satisfactorily with such a shift by means of conventional damage remedies or the defenses of frustration and impossibility. Such judicial remedies, however, are hardly perfect; they are expensive to both the litigants and society, and they are subject to error. Undesirable performance, unwarranted outlays, and an element of risk could be the outcome of making the institutional choice to rely solely on the judiciary. Thus, one can imagine a situation in which legislation that released parties from their obligations and offered some rough approximation of the resulting damages might improve the contracting process and the protection of private property. ${ }^{183} \mathrm{I}$ would not argue

191 "No State shall . . . pass any . . . Law impairing the Obligation of Contracts . . . " U.S. ConST. art. I, § 10.

${ }_{102}$ J. ELY, supra note 15, at 92.

${ }^{193}$ The Court confronted an issue of this sort in Home Bldg. \& Loan Ass'n v. Blaisdell, 
that such a solution is desirable. My argument is that if the contracts clause forecloses such legislative action, it promotes the postulated substantive value only if important and not obvious institutional assumptions are made about the market, the judiciary, and the legislative processes.

The religion clauses ${ }^{184}$ are susceptible to the same analysis. Does it necessarily follow that forbidding congressional action on religious grounds increases religious freedom, the value which Tribe claims is embodied in those clauses? Even if the first amendment seems to enhance religious freedom by forestalling congressional interference, religious freedom may also be stymied by private individuals through violence, economic discrimination, or threats of either. Under such circumstances, it is possible to imagine that government action could promote religious freedom by equalizing the ability of the adversely affected groups to worship. ${ }^{185}$ Likewise, it is possible to imagine a religion so hateful of, and demeaning to, other religions that its practice would deter the practice of other religions. The totality of religious freedom might be promoted by government action presumably precluded by the existing constructions of the "free exercise" clause.

The religion clauses represent a sensible perception of a major source of danger to religious freedom in the form of governmental interference. The framers were no doubt influenced by the past excesses of government and it is wise to fear such excesses today. But if the clauses are wise or sensible, and if they promote the goal suggested, they are so and do so because of institutional factors. Under other institutional assumptions, the religion clauses might be inconsistent with religious freedom, just as the contracts and compensation clauses might be detrimental to the protection of private property.

Consideration of the religion clauses raises issues of more general import. Tribe finds importance in values associated with "per-

290 U.S. 398, 416-17 (1934), where it upheld a Minnesota depression-era statute authorizing the judiciary to extend the period of redemption from mortgage foreclosure sales and to require payment by the mortgagor of appropriate damages.

194 "Congress shall make no law respecting an establishment of religion or prohibiting the free exercise thereof . . . "U.S. CONST. amend I.

195 Congress has enacted analogous legislation to alleviate race and gender inequality. See, e.g., Education Amendments of 1972, Pub. L. No. 92-318, tit. IX, § 901, 86 Stat. 235, 373 (codified at 20 U.S.C. $\$ 1681$ (1982)); Act of Sept. 6, 1966, Pub. L. No. 89-554, §§ 7151, 7154(b), 80 Stat. 378, 523 (codified at 5 U.S.C. $\$ \S 7201,7204$ (b) (1982)); Equal Pay Act of 1963, Pub. L. No. 88-38, § 3, 77 Stat. 56, 56 (codified at 29 U.S.C. $\$ 206$ (d) (1982)); see also supra note 116 and statutes cited therein. 
sonhood" or privacy. ${ }^{196}$ Although the terms are vague, they seem to be related to the ability of an individual to enjoy personal fulfillment through choices about sexual preference, the bearing of children, and general lifestyle. Unfortunately, Tribe, ${ }^{197}$ and others who have explored and described these values, ${ }^{198}$ have largely ignored an important consideration-not surprisingly, an institutional consideration. They have not carefully considered who should decide when an interference with personal fulfillment has occurred and who should decide on its remedy.

There is no doubt that political entities are a potentially serious source of interference with personal fulfillment in the form of sexual and lifestyle choice. As with religion, however, in matters of personal fulfillment government is not the only source of serious interference. Individuals or private groups are capable of interfering with these choices, and government action might provide the best protection against such private interference. More importantly, perhaps, where there is substantial interaction among individuals, the ability of one person to adopt a given lifestyle or express himself or herself may affect, and be affected adversely by, another's attempts to do so. Someone must define the limits beyond which one individual's lifestyle or self-expression becomes an infringement on the lifestyles and self-expression of others. There can be no "freedom" without some level of governmental or collective action.

Again, I am not arguing that the legislative branches are necessarily preferable to the judiciary in promoting these values. Such a statement would require a more careful institutional comparison than our present understanding allows. I am contending that to characterize a value as societally important does not take us very far in understanding or evaluating the constitutional assignment of responsibility for implementing that value.

This observation brings me to the most general concern of those who adopt the "substantive" position, namely, the concept of "fundamental values" or "fundamental rights." Ely criticizes the notion of fundamental values in the following terms:

[T] he list of values the Court and the commentators have tended to enshrine as fundamental is a list with which readers of this book will have little trouble identifying: expression, as-

196 See L. TRIBE, supra note 33, at 886-90; Tribe, supra note 99, at 1069-72, 1075-77.

197 See L. TrIBE, supra note 33 , at $886-90$.

${ }^{183}$ See, e.g., Karst, The Freedom of Intimate Association, 89 YALE L.J. 624 (1980) and material cited therein. 
sociation, education, academic freedom, the privacy of the home, personal autonomy, even the right not to be locked in a stereotypically female sex role and supported by one's husband. But watch most fundamental-rights theorists start edging toward the door when someone mentions jobs, food, or housing: those are important, sure, but they aren't fundamental. ${ }^{199}$

Ely simply dismisses such listmaking as beyond the capacity and legitimate authority of the judiciary, a position I have already criticized as too sweeping. ${ }^{200}$ But an essential point remains: Why are values such as expression and education arguably more fundamental than housing, food, jobs, and, one might add, peace and war?

The answer may lie in the institutional role served by the concept of "fundamental rights." In the present constitutional jurisprudence, a finding that legislation affects a fundamental right tends to remove that issue from the legislative process and allocate responsibility for its determination to the judiciary. ${ }^{201}$ If housing, jobs, food, commerce, taxation, national defense, and foreign affairs were declared "fundamental values," the judiciary would have to take a serious hand in their effectuation.

These subjects are not excluded from the list of "fundamental values" because they are unimportant. If anything, they are excluded because they are too important. More exactly, they are excluded because the relative institutional abilities of the legislative process vis-a-vis those of the judicial process are thought to favor the former. This observation is not meant to suggest that the legislative process is ideal or close to ideal as an arbiter of these questions, but only that, as a general matter, the judiciary is not thought to be a superior arbiter and has, therefore, generally stayed away from these subjects.

I have sounded two major themes here which need summary. First, I have suggested a hypothesis about the meaning of fundamental rights, at least as that term is employed by the Court. It is commonly stated that in constitutional decisionmaking one must first inquire into the nature of the rights involved in a given issue and from the result of that inquiry flows the institutional choice of the appropriate decisionmakers: if the rights are fundamental then the judiciary should closely scrutinize the actions of the political

\footnotetext{
209 J. ELY, supra note 15, at 59 (footnote omitted).

${ }^{200}$ See supra notes $119-41$ and accompanying text.

${ }^{201}$ See e.g., Griswold v. Connecticut, 381 U.S. 479 (1965).
} 
process, if not then the political process is allowed a fairly free hand. I have argued that the converse is a more accurate portrayal of the causal link between institutional choice and fundamentality-where there is greater perceived need for judicial scrutiny then a right will be characterized as fundamental.

Second, and most important here, institutional choice and comparison is a necessary part of any constitutional theory. The recognition and isolation of a value or set of values is inadequate or incomplete. Governmental interference is never the sole source of danger to any value. Unconstrained individual choice is also always present as a source of danger. Whether the goal is protection of private property, or the freedom to worship as one desires, or the choice of lifestyle, or anything else, there are potential dangers from other individuals which may call for governmental redress, as well as potential dangers from the governmental interference itself. Therefore, an inevitable question arises as to who should decide when government interference is appropriate.

It seems self-evident that the Constitution is about substance. I cannot conceive of the framers, founders, or ratifiers as interested in running a social scientific experiment in democratic theory. The preamble sets out substantive goals. One can add to and subtract from this list of goals and attempt better to define its content. Travel through the Constitution reveals, among others, interests in religion, private property, slavery, equal treatment, defense, commerce, public works, taxation, just criminal proceedings and punishment, and the fair allocation of the franchise. Tribe, in other words, is correct when he insists that the Constitution concerns what it means to be an individual or a citizen.

But the Constitution reflects another self-evident reality-reality is not self-evident. Even if the goals reflected in the Constitution could be better defined, ordered in some way, or boiled down to a simple overriding value or goal-the apparent purpose of a great deal of constitutional scholarship-we would still be a long way from understanding what the Constitution is, will be, or ought to be. Any goal or interest or set of goals or interests must be implemented by imperfect institutions in an uncertain and changing world. However we define what it means to be an individual or a citizen in our society, we will have to give careful consideration to the manner in which this individualness or citizenship is to be implemented, protected, and accommodated with other demands. 


\section{B. Interpretivism}

Interpretivists or originalists maintain that the content of constitutional law should be determined by the intentions of the framers or ratifiers of the particular provisions of the Constitution. This position is generally viewed as the polar opposite of the fundamental rights position, ${ }^{202}$ but, as I have noted, the two positions share the view that comparison of institutions is largely irrelevant. If one accepts the premise that the intention of the framers should control and that the historical record clearly establishes their intention as to either substantive or institutional choices, the need for an independent comparative institutional analysis is, in such instances, concededly reduced.

There are two well-established criticisms of the originalist logic. The first takes the normative position that the present generation should not be entirely constrained by the intentions or understandings of a past generation. ${ }^{203}$ The second invokes the inherent difficulty of determining or even defining collective intent. ${ }^{204}$ Many groups have figured in the making of the Constitution-framers, ratifiers, and citizens. Each group is itself an aggregation of individuals. How is one to know which among often conflicting views prevailed? Should heavier weight be given to the comments of proponents or to those of opponents of a particular provision? Should statements made in one context be weighed more heavily than those made in another? What did silent participants intend? In particular, what did the voting public or the mass of state legislators believe they were doing? The evidence at hand, moreover, is often meager; discussion was not always extensive or documented, and the documents have not always been preserved.

These points aside, it is important to see that even if the Constitution had been framed by one individual whose intentions were clear, and even if contemporary decisionmakers felt themselves completely bound by those intentions, the interpretivist approach could not resolve today's cases without recourse to some external criterion-whether it be moral philosophy, comparative institutional analysis, or tea leaves.

The interpretivist I have chosen for my analysis is Raoul Berger. In his much discussed book, Government by Judiciary, ${ }^{205}$ Ber-

${ }^{202}$ See J. Ely, supra note 15, at 1, 43.

${ }^{203}$ See, e.g., Dworkin, The Forum of Principle, 56 N.Y.U. L. REv. 469, 476-82 (1981).

${ }_{204}$ See, e.g., Brest, The Misconceived Quest for the Original Understanding, 60 B.U.L. Rev. 204, 229-34 (1980).

${ }^{208}$ R. BERGER, Government by JUdiciary (1977). 
ger argues that the records of the Thirty-Ninth Congress are detailed and extensive enough to establish solidly that the framers of the fourteenth amendment did not intend that any of the clauses of the first paragraph should provide rights to vote or rights to enjoy racially desegregated public facilities, especially not schools. To Berger, the record shows that these clauses were meant simply to protect the civil rights of recently freed slaves and that, by civil rights, the framers meant only the traditional common law rights to contract for purchase and sale of labor and other assets, to have access to the courts for enforcement of contracts and redress of other potential civil injuries, and to receive equal treatment in the enforcement of and the protection afforded by the criminal law. The amendment and the Civil Rights Acts ${ }^{206}$ it supported were a reaction to the Black Codes passed by many of the former slave states. The members of the Thirty-Ninth Congress thought these codes severely reduced the ability of the former slaves to function as free people. The debates make clear to Berger, however, that Congress also reflected a significant amount of the "Negrophobia" then gripping the populace. The record clearly shows, he argues, that most members of Congress rejected the idea that the fourteenth amendment included voting and school desegregation among the civil rights it protected. ${ }^{207}$

Some have criticized Berger's reading of the historical sources, ${ }^{208}$ but that is not the relevant issue here. Even if Berger's reading of the historical record is correct, it does not by itself determine the outcome of the voting rights and school desegregation cases decided in the twentieth century.

Let me make my point by the use of a simple parable. Suppose that a person owns land in a remote jungle-a jungle without any means of communication. Some time in the past he visited this land and surveyed its terrain and resources. Now he wishes the land developed. Although he would prefer to oversee the task himself, he cannot make the trip. Instead, he appoints an agent and gives her the following instructions. (1) Build a dam to control the

208 Civil Rights Act of 1870 , ch. 114, 16 Stat. 140 (current version codified at 42 U.S.C. $\S \S 1971,1981,1987,1989-1991$ (1982)); Civil Rights Act of 1866, ch. 31, 14 Stat. 27 (current version codified at 42 U.S.C. \$ 1982, 1986-1987, 1989-1992 (1982)).

${ }^{207}$ See R. BERGER, supra note 205, at 20-36, 52-68, 117-33, 166-214.

${ }^{20 s}$ See, e.g., Kutler, Raoul Berger's Fourteenth Amendment: A History or Ahistorical?, 6 Hastings Const. L.Q. 511 (1979); Soifer, Protecting Civil Rights: A Critique of Raoul Berger's History, 54 N.Y.U. L. Rev. 651 (1979); Murphy, Book Review, 87 YaLE L.J. 1752 (1978). For an extensive summary of the critiques of Berger and his replies, see Gangi, Judicial Expansionism: An Evaluation of the Ongoing Debate, 8 OHIO N.U.L. Rev. 1 (1981). 
river which courses through the property. If the river is not controlled, the development operations such as mining and timbering cannot be carried out. (2) Construct the dam of materials on the site. There are several kinds of trees on the land which should provide more than sufficient material to build the dam. (3) Do not use two of the types of trees-teak and rosewood-in constructing the dam. These trees are valuable and should be kept for other purposes.

With these instructions, the agent sets out to develop the remote land. When she arrives, she finds that the river is more powerful and less controlled than when the landowner had visited. She also finds that the supply of trees other than teak and rosewood has diminished significantly since his visit. The agent attempts to build a dam from these other trees, but the flooding is only partially controlled and the timbering and mining are not fully protected. In fact, as time goes by, the makeshift dam seems increasingly inadequate to control the flooding and protect the mining and timbering operations, which are becoming more extensive and complex. Eventually, it appears to the agent that any realistic success at mining and timbering requires greater protection from flooding than can be achieved except by using the forbidden teak and rosewood trees on the dam. The agent is faced with an obvious quandary. Lacking direct recourse to the landowner, she has only his words to rely on-words uttered with reference to a conception of the task that no longer conforms to circumstances as they actually exist.

The framers of the fourteenth amendment sought to protect what they thought to be key civil rights. In their view, such rights did not include voting or desegregation. Yet, after more than one hundred years, the post-World-War-II Court might well believe that the basic civil rights that the Thirty-Ninth Congress intended to protect had not in fact been secured by such means as the Civil Rights Acts. Fear of state authorities, indifference by federal authorities, and perhaps ignorance among the populace effectively denied blacks the rights that were in theory secured to them by the fourteenth amendment. The problems thought inherent in the Black Codes seemed present in other laws and practices, and these obstacles had not been removed or controlled by access to direct legal action under the Civil Rights Acts.

The situation in the mid-twentieth century is no doubt more complex than this account suggests, but it would not be unreasonable even for an interpretivist judge to have observed a failure to achieve the goal of the fourteenth amendment-the protection of 
those basic civil rights necessary for a person to function in society as a free individual. Such a judge might seriously consider the need for different steps-even those once forbidden by the framers-in order to carry out the framers' mandate. Better education, the interaction of the races in schools, and more meaningful access to the vote are plausible means for securing real access to basic civil rights in the face of a century of hostility and indifference. The interpretivist judge would be faced with conflicts between the mandate to secure basic civil rights and the framers' apparent prohibition on federally mandated integration of public facilities or enfranchisement of blacks.

But I have not completed my parable. If the landowner is the analogue to the framers, then, consistent with my earlier discussion, the agent is really a set of future decisionmakers-not just the judiciary. Thus, to return to the parable, the landowner might have sent several agents to develop the land. But now there must be some indication of which tasks are to be carried out by which agent. What are the instructions on the allocation of tasks in Berger's version of the fourteenth amendment? In particular, who is to resolve the conflict between the basic mandate and the specific prohibitions?

The underlying distrust of state governments inherent in the fourteenth amendment reduces their claim as primary candidates for the task, leaving us with two alternatives-Congress and the judiciary. Here Berger might well argue that the framers showed a clear preference. Section five of the fourteenth amendment provides that "Congress shall have power to enforce, by appropriate legislation, the provisions of this article." ${ }^{209}$ By Berger's own reading of the record, however, that provision presumed that the protection of basic civil rights could be accomplished by the means that seemed acceptable at the time-the Civil Rights Acts. Would the same allocation of tasks have occurred if the inadequacy of those Acts had been foreseen? The members of the Thirty-Ninth Congress may well have trusted themselves to resolve unforeseen conflicts between mandates and prohibitions. But the conflict did not surface in its present form in 1868. The appropriate question for an interpretivist must be whether the members of the ThirtyNinth Congress would have chosen twentieth-century Congresses over twentieth-century courts or even the modern state legislatures to resolve a conflict that, at the time the fourteenth amendment 
was adopted, did not appear to be major. ${ }^{210}$

Thus, when an interpretivist judge seriously considers the conflict between the fourteenth amendment's mandate to protect civil rights, on the one hand, and the framers' desires to avoid interference with state control of voting and separation of the races, on the other, he or she must also consider how the framers intended that such a conflict be resolved. The relationships among Congress, the courts, and the states must have been considered in some rough sense in 1868. Presumably, allocation of institutional roles was a product of those perceptions-including the perception that the civil rights in question could and would be secured sufficiently and quickly by congressional action. There have been shifts in that perception as well. The interpretivist judge, like the agent-overseer, arrives at his or her remote place in time to find conditions significantly different and his or her basic instructions in conflict. Someone must attempt to resolve these conflicts. Perhaps the record is clear enough to resolve these conflicts by reference to the intent of the framers. It does not look so to me.

Interpretivists like Berger concede that the Constitution leaves many gaps which require future decisionmaking and, more importantly, future allocation of decisionmaking responsibility. Once one notices, however, the difficulty of matching perceived goals and the institutional mechanisms for their realization over long periods, the concession seems to give away the game. ${ }^{211}$

${ }^{210}$ Berger himself notes that the first section of the fourteenth amendment was enacted in fear of actions by subsequent Congresses. See R. BERGer, supra note 205, at 23. As a general matter, the interpretivist judge may have trouble finding determinate institutional answers in most constitutional contexts. When the framers of the Constitution set out to achieve goals and set conditions, they did so under conditions likely to make them appreciate not only that institutions are limited, but also that allocations of decisionmaking authority among institutions are likely to be unstable over time. In his excellent work on the evolution of political thought in the period between the Declaration of Independence and the Constitution, The Creation of the American Republic, 1776-1787, Gordon Wood describes significant shifts in perceptions of how best to allocate institutional responsibility in order to achieve the goals envisioned by the founders. See G. Wood, supra note 155, passim. These shifts revealed deep uncertainty about the constitutional forms and institutional allocations suited to the needs of the new republic. It is difficult to believe that those who framed or ratified the original Constitution were committed to a firm and fixed institutional allocation projected into the indefinite future if, in little more than a decade, perceptions about institutional allocation had changed so dramatically and remained so controversial.

211 There are two additional reasons why the originalist position is limited as a mode of constitutional analysis. First, the originalists do not supply us with any means to describe constitutional law as it has developed in this century. Second, even if the originalists abandon description and seek solely to reform constitutional law, they must nevertheless face serious institutional questions that they have not adequately addressed.

One purpose of constitutional analysis is to achieve a greater understanding of the law 


\section{Conclusion}

I am told that Mark Twain often began his talks with a dramatic pause, followed by the announcement: "Aristotle is dead. Plato is dead. Goethe is dead. Nietzche is dead. And I don't feel so well myself."212 I recognize that this is an introductory piece which can only serve the purpose of presenting the outlines of comparative institutional analysis and of clearing the way for its expansion and testing. Like the approaches I have criticized, the approach I

as it exists. Berger, however, eschews any descriptive role for the originalist approach. Berger believes that many major decisions of this century are inconsistent with the intent of the framers. He seems to recognize that there is virtually no jurist who has ever consistently toed the originalist line. See R. BERGER, supra note 205, at 56-98 (reapportionment cases), 249-82 (substantive due process cases), 338-50 (Burger Court death-penalty cases), 397-406 (Burger Court trial-by-jury decisions). While no theory of constitutional analysis can claim to provide a wholly accurate description of actual decisionmaking, the originalist position seems especially ill-suited to the task.

The second problem is related to the critical stance taken by authors like Berger. If, as Berger argues, judges always have proclaimed adherence to the intent of the framers and have then violated their proclamations in practice, one must doubt the prescriptive as well as the descriptive power of the originalist approach. If, despite pronouncements before and after appointment, judges stray, then how might they be stopped? The originalists must present a means of implementing their reform at some acceptable cost.

Education and exhortation spring first to mind. But original intent is not a concept about which judges are unaware; many judicial arguments are framed in precisely such terms. Nor are judges so unable to comprehend or search out original intent that reform can come simply by showing them the way. According to Berger, some of the prime examples of research into original intent have come from the pens of judges (or their clerks) and have been ignored by their fellow judges.

Another possibility for implementing the originalists' program is to work through the appointment process, seeking to seat more originalist judges. It is my impression, however, that Presidents have tried to follow such a course and have found their predictions of adherence to originalism to be quite unreliable.

As one looks beyond the appointment power, the reforms become increasingly expensive. Congress-if it could be convinced of the virtues of original intent-might remove jurisdiction from the Court in areas where there has been serious transgression, assuming that Congress has such power and could identify such instances. But such a step may itself violate the framers' original intention of employing the Court as a negative check on Congress. In addition, the reallocation would have to be severe if it were aimed at stopping a determined judiciary. What the judiciary cannot do by constitutional review, it can often do by statutory interpretation. Imposing limits on those powers threatens to reform the judiciary away.

So far as I understand, originalists do see a role for judicial review and the invalidation of legislation on constitutional grounds. Perhaps because they are legal scholars long imbued with the notion that the judiciary plays an important role in the constitutional scheme, if only in its common law role as an administrative arm of the legislature, the originalists would likely wish to stop significantly short of a massive reduction of the judicial role. But, in order to elevate their critique into reform, they must face the institutional questions of how and at what cost greater adherence to original intent will come.

${ }^{213}$ My source here is my colleague Willard Hurst. Should, by chance, the story be apocryphal, we may at least assume it is the sort of thing Twain would have said. 
suggest has its limits and no doubt its defects.

It is my belief that a comparative institutional approach to constitutional law will yield important intellectual returns for both positive and normative analysis. I have examined some important constitutional cases to show that relevant institutional factors seem essential to understanding and evaluating them, and have examined the approaches of others to extract general lessons about institutional analysis and its relevance.

I am aware that a few applications and a look at the gaps in existing approaches do not establish the superiority of the comparative institutional approach. Only the criticism of others, including, I hope, the commentators I have discussed, can prove the mettle of the approach suggested here. If comparative institutional analysis is to be advanced and tested, time and effort must be expended on careful studies of specific constitutional questions. I hope that I have begun to lay the basis for such studies, and for intellectual interchange about the role of institutional comparison in constitutional law. 